\title{
Can the historical gender gap index deepen our understanding of economic development?
}

\author{
Faustine Perrin ${ }^{1,2}$ \\ ${ }^{1}$ BETA, University of Strasbourg, Strasbourg, France and ${ }^{2}$ Department of Economic History, Lund \\ University, Lund, Sweden \\ Corresponding author. E-mail: faustine.perrin@ekh.lu.se
}

(Received 24 February 2020; revised 4 November 2020; accepted 4 November 2020; first published online 1 March 2021)

\begin{abstract}
Knowledge of the long relationship between gender equality and economic growth is hampered by the lack of information and resources on the various dimensions of gender equality. This paper is a first attempt to assess the size of the gender gap and investigate its relationship with economic growth from a historical perspective. Exploiting a unique census-based dataset of 86 French counties in the mid-nineteenth century, I construct a historical gender gap index measuring the size of the gap between men and women in three critical areas: economic opportunities, educational attainment, and health. A county comparison allows me to identify the strengths and weaknesses of French counties in closing the gender gap. I find that France can be divided into two main areas, the North and the South. In particular, the Northern counties that have done most to narrow the gap display better economic performance. Boys' and girls' education and family structures appear to be crucial determinants of gender equality. Gender equality is positively and significantly associated with economic performance. Accounting for the multi-dimensions of gender equality is crucial for economic development.
\end{abstract}

Key words: Development process; France; Gender equality; Index; Nineteenth century

JEL classification: J16; N33; O11

\section{Introduction}

The promotion of gender equality, together with the economic and social empowerment of girls and women, has been reassessed to form a global goal of the 2030 agenda for achieving sustainable and prosperous development. By removing the barriers that prevent women from accessing-as men do-human capital endowments, economic opportunities and human rights, gender equality may allow economies to perform better and to improve economic development. Despite improvements in gender equality and female empowerment since the achievement of the Millennium Development Goals, gender differences persist and continue to be a major challenge for both developed and developing countries. Hence, it is essential 
to better understand the relationship between gender equality and economic development. This paper aims at improving our understanding of gender equality and its relationship with economic development in a historical perspective.

A number of theoretical contributions have suggested the existence of a negative link between gender inequality and economic growth [e.g., Galor and Weil (1996), Lagerlöf (2003), De la Croix and Van der Donckt (2010), Prettner and Strulik (2017); among others]. ${ }^{1}$ Among them, Diebolt and Perrin $(2013,2019)$ emphasized the role played by greater gender equality in the decisions made by family members (in terms of children's education, for instance) that influence in turn long-term economic and demographic changes. The empirical literature that links gender equality and economic development based on contemporaneous data is abundant [see, for instance, Goldin (1990, 1994), Schultz (1995), Dollar and Gatti (1999), Klasen (2002), Knowles et al. (2002), Doepke and Tertilt (2009), Klasen and Lamanna (2009).$_{.}^{2}$ However, few empirical studies focus on gender inequalities in earlier periods (i.e., using historical data). Among them, a few have recently measured the gender wage gap during the modern era [see Humphries and Weisdorf (2015), regarding England; Gary (2017), regarding Sweden; and De Pleijt and Van Zanden (2018), with regard to a group of European countries]. These works contribute to the deeper improvement of our understanding of gender relations over the long run but can measure only one dimension of gender inequality. Yet, as shown by De la Croix and Van der Donckt (2010), the various dimensions of gender disparity have different effects on shaping the development process. Gender equality is a multidimensional concept and a comprehensive measure of gender parity must encompass a wide range of gender-based indicators if it is to capture the various dimensions of gender equality, and consequently the various channels through which gender equality may foster economic development.

Despite improvements made to measure gender equality, no equivalent tools exist at the historical level, in particular because of data limitations. ${ }^{3}$ Consequently, our knowledge of gender (in)equality in the past remains largely limited to qualitative investigations. The paper builds an indicator measuring the size of the gender gap from a historical perspective following the methodology developed by Hausmann et al. (2006) - within the project launched by the World Economic Forum in 2005. This index captures the size of the gap between men and women in four critical areas:

\footnotetext{
${ }^{1}$ See Klasen and Santos Silva (2018) for a detailed and exhaustive survey of the theoretical literature linking gender (in)equality and economic development, and review of the plausible mechanisms through which inequality between men and women affects the aggregate economy.

${ }^{2}$ See Duflo (2012) for a review of the literature on the empowerment-development nexus, and Cuberes and Teignier (2014) for a presentation of the empirical literature.

${ }^{3}$ Since the seminal work of Yllö (1984), in which the author constructed an indicator to measure the existing gender inequality in the US, several international comparative gender equality indices have been developed. Each index integrates its own list of parameters affecting the outcome for each country. In 1995, the United Nations Development Program presented two indicators designed to reflect gender disparities in basic capabilities: the Gender-Related Development Index (GDI) and the Gender Empowerment Measure (GEM). Alternative measures have since been developed to remedy the methodological and conceptual limitations raised by Bardhan and Klasen (1999), Dijkstra and Hanmer (2000), and Schüler (2006), among others. Within these alternatives, one can find the gender gap index (GGI), developed by the World Economic Forum [Hausmann et al. (2006)], and more recently, the Social Institutions and Gender Index (SIGI), measuring instances of discrimination against women [Branisa et al. (2014)].
} 
economic participation and opportunities, educational attainment, health and survival, and political empowerment. Gender equality is considered achieved when women and men have the same rights and opportunities across all sectors of society, and when their behaviors, aspirations, and needs are equally valued and favored. Extending this line of research to a historical period, Perrin (2014) proposed a first attempt to measure the size of the gender gap in the past-which is further developed in the current paper. Recently, using a similar methodology, Dilli et al. (2019) calculated a gender equality index for a collection of 129 countries during the period 1950-2003. They found that countries made substantial progress in gender equality over the past 50 years but that little convergence between countries could be observed.

Based on a unique dataset built up from the Statistique Générale de la France, I created a county-level historical gender gap index measuring the extent to which women achieved equality with men across France in the $1850 \mathrm{~s}^{4}$ Mid-nineteenth century France is a particularly interesting case to study. France was experiencing its economic takeoff while its demographic transition had already been under way for about 50 years. ${ }^{5}$ Besides, the country presents exceptional regional diversity on various dimensions-economic, demographic, social, cultural-reflecting the different stages of development reached by the regions [see Perrin (2013)]. The ambition to construct a historical gender gap index was twofold. First, this index is used to pinpoint regional variations in the distribution of opportunities and resources between genders during the modernization in France. Second, this index opens the door for new empirical insights in investigating the consequences of gender differences in the middle of nineteenth century France on the country's economic development. Using the heterogeneity of the county gender gap index, preliminary tests reveal that the French counties that came nearest to closing their gender gap display better economic performance and exhibit lower fertility rates. The analysis also shows that when comparing the effect of the sub-indices separately, the overall index-which compasses the wider variety of gender indicators-captures far more variations in economic performance than any of the sub-indices.

The remainder of the paper is structured as follows. Section 2 describes the methodology and steps followed to build the historical gender gap index. Section 3 presents the gender-based dimensions and variables necessary for the construction of the index. Section 4 presents the strengths and weaknesses of France in closing the gender gap and investigates a range of possible determinants. Section 5 provides an overview of the county-level relationship between gender-related conditions and economic performance. Section 6 summarizes and concludes.

\section{Methodology: the construction of the index}

This paper aims at capturing gender-based disparities in various dimensions from a historical perspective. The county-level gender gap index is constructed using a five-step process, as done by Hausmann et al. in the computation of the gender gap index 2006. This procedure is applied to all gender-related indicators integrated to build the index.

\footnotetext{
${ }^{4}$ To be able to make this possible, one is required to work on a period from which good information can be found at a gendered disaggregated level. My work therefore focuses on the middle of the nineteenth century, a period from which the French statistical office substantially improved its method of collecting data by gender.

${ }^{5}$ The estimated timing of the French fertility decline differs from one study to another depending on the measure of fertility and/or method used. Wrigley (1985) estimates the transition to start around 1800, Cummins (2009) in 1776, Blanc (2020) in the 1750s, to give a few examples.
} 


\subsection{Step 1: conversion to ratios}

In order to capture gender equality per se, my index measured the position reached by women relative to the position reached by men. A county was rewarded (or penalized) on the basis of the size of the gap between men and women, but not for its overall levels. This strategy enabled me to account for gender equality independently of the level of development, i.e., without economic-related a priori on the data. Indeed, people living in richer counties are likely to present greater educational attainment than people living in poorer areas. Nevertheless, such counties could exhibit wide gender inequality. Conversely, less developed counties could present low educational attainment but limited gender inequality. ${ }^{6}$ Accounting for gaps allowed me to account for the various possible scenarios by focusing strictly on gender differences, all other factors being equal. Hence, I first converted all the data into female-to-male ratios. To give an example, a county with $30 \%$ girls and $62 \%$ of boys enrolled in primary schools was assigned a ratio of $30 / 62=0.48$ on this variable. Such a ratio meant that girls had closed $48 \%$ of the gap with boys in primary school enrollment. For approximately 2 boys enrolled in primary school, then, 1 girl is enrolled.

\subsection{Step 2: data rescaling and truncation at the equality benchmark}

The second step of the process involved: (i) rescaling the natural female-to-male ratios to the equality benchmark; and (ii) truncating the ratios to one. The truncating procedure enabled me to assign the same score to counties that had reached parity between women and men and to those where women had out-done men. The rescaling procedure allowed me to account for natural differences between men and women. The equality benchmark was taken to be 1 -meaning equal numbers of women and men-on all variables except those of health. Taking the example of the sex ratio, this gender-based indicator varied according to the age profile of the population. It may also have been affected by environmental and social factors. Grech et al. (2002) have estimated the natural sex ratio at birth to be circa 1.06 men per 1 woman. Accordingly, the equality benchmark is set to be 0.944 to correct for the natural factors of the sex differential. Similarly, the reversed mortality ratio and the life expectancy ratio were truncated according to the equality benchmark set at $1.06 .^{7}$ I employed the reversed value of the mortality ratio to have the same sign in interpretation (i.e., the higher the value, the better the score). It integrated the positive effect of having a low mortality ratio in the health outcome. Once the indicators were rescaled to the equality benchmark (1), the ratios were truncated to 1 as the highest possible level of gender parity.

\subsection{Step 3: calculation of weighted averages}

The gender gap index is a composite indicator. Each gender-related dimension-based on economic, education, and health criteria (described in section 3)-constitutes the sub-indices that I used to construct the overall gender gap index. As a third step, I calculated the weighted average of the variables within each sub-index to create the

\footnotetext{
${ }^{6}$ Accordingly, counties can be ranked on their gender gaps and not on their level of development. The gender gap index rewards counties based on their smaller gaps, regardless of the overall level reached.

${ }^{7}$ This ratio was based on the standards used in the UN's Gender-Related Development Index, which uses 87.5 years as the maximum age for women and 82.5 years as the maximum age for men.
} 
sub-index scores. This computation aimed to give the same weight to each variable because some variables exhibited greater volatility than others, e.g., larger standard deviation [see Sugarman and Straus (1988) and Harvey et al. (1990)]. The calculation of sub-index scores involved: (i) calculating the standard deviation for each variable; (ii) normalizing variables by equalizing their standard deviations to determine the percentage change in terms of standard deviation to a $1 \%$ change of each variable; and (iii) using these weights to calculate the weighted average of the variables.

\subsection{Step 4: calculation of sub-index scores}

I now turn to the way in which I calculated the weighted average score of the sub-indices. This process ensures that the same relative impact would be integrated into the sub-indices for each variable, so that a variable for which most counties had already reached equality would be penalized. For example, the wage ratio in industry has a relatively small standard deviation. The wage ratio gets greater weight in the economic opportunity sub-index, while the labor force ratio in industry has a larger standard deviation. Similarly, for any variable characterized by a higher ratio and lower variability (i.e., greater weight), a county that would deviate would be more heavily penalized.

\subsection{Step 5: calculation of final scores}

Finally, I calculated the scores of the indices. All the sub-indices were bounded between 0 and 1 to allow for cross-county comparisons. The value 0 corresponded to perfect imparity; 1 to perfect parity. To create the overall gender gap index, I brought together the three sub-indices by simply taking their (un-weighted) average at the county level. The final score was also bounded between 0 and 1 .

\section{Data}

The construction of such an index was constrained by the availability of the data. I explore the size of the gender gap from gender-related variables belonging to three critical categories: (i) economic participation and opportunity; (ii) educational attainment; and (iii) health and survival. ${ }^{8}$

\subsection{Multiple dimensions of gender-based disparities}

I use county-level data collected from diverse publications of the Service de la Statistique Générale de la France. The French Statistical Office publishes data since 1800. But from 1851, the Statistical Office provided data ranking population by age, gender, marital status, and other essential information used to build a measure of the gender gap. The dataset covers information about aggregated individual-level behavior for 86 French counties (départements). The major part of the dataset is constructed from

\footnotetext{
${ }^{8}$ Gender gap indices based on contemporaneous data account for political empowerment, such as the number of female to male seats in parliaments. There are no such data that could be used to measure political empowerment at the county level. Besides, in mid-nineteenth century France, women were excluded from political power. The political empowerment sub-index would therefore represent perfect imparity and would not allow any discrimination between counties. Accordingly, my index does not account for political criteria.
} 
general censuses, statistics of primary education, population movement, and agriculture survey conducted in the 1850s; and from industrial statistics conducted in 1861. I combined the various censuses to construct a dataset with gender-related detailed information on employment and wages in industry and agriculture, literacy rates, enrollment rates in primary schools, population, longevity, and mortality.

\subsubsection{Economic criteria}

Four variables were used to capture the size of the gender differences in economic opportunity and participation. The share of people employed in manufacturing and the share of people making their living from agriculture in 1851 were used to measure the difference in participation in the labor force between men and women. The average hourly wages (in francs) in industry and in agriculture were used as proxies to measure differences in remuneration.

\subsubsection{Education criteria}

Three variables were used to measure gender differences in education: enrollment rates, literacy rates, and public schools. Enrollment rates in public primary school measure educational attainment. Enrollment rates are calculated as the number of boys/girls attending school divided by the total number of boys/girls aged 5-15. The literacy rate is a proxy measuring the long-term ability of individuals to read and write. The third variable included in this sub-index is the number of public schools for boys/girls, used to capture the sex-differential in the infrastructure. These variables were used as a proxy to measure the differences in institutional investment between boys and girls.

\subsubsection{Health criteria}

Three variables were used to capture gender differences in health and survival: the number of births of boys and girls (in 1851), the mortality rate of men and women (in 1851), and the life expectancy of men and women (in 1856). The differences between the birth numbers for boys and girls may be skewed by factors such as infanticide. It reflects households' potential preference for sons (society's valuation of women) or, inversely, women's ability to protect vulnerable female children. Mortality rates were calculated as the number of men/women who died per 1,000 living men/women. Finally, the construction of a measure of life expectancy at birth involved several steps. I calculated a life table at the county level, splitting the population into 5-year age bands and the deaths into 5-year age bands (as detailed in Appendix B). These data were available for the year 1856 by combining data from the Census and from the Population Movement. Both the mortality and the life expectancy ratios captured the mortality differential potentially triggered by violence, malnutrition, or disease. Appendix A describes all the data and sources in greater detail.

\subsection{Descriptive statistics of gender differences}

Table 1 reports the descriptive statistics of the variable used to construct the gender gap index. The share of individuals working in the agricultural sector was high for both genders, while the share of individuals making their living from working in industries was low. In 1851, almost $74 \%$ of men and $61 \%$ of women were working in agriculture, but respectively only $6 \%$ and about $4 \%$ in industry. Moreover, the 
Table 1. Summary statistics of the variables

\begin{tabular}{|c|c|c|c|c|c|}
\hline Variables & Obs. & Mean & $\begin{array}{l}\text { Standard } \\
\text { deviation }\end{array}$ & Min. & Max. \\
\hline \multicolumn{6}{|l|}{ Economic variables } \\
\hline Male labor force in agriculture & 86 & 0.7368 & 0.1713 & 0.0462 & 1.1349 \\
\hline Female labor force in agriculture & 86 & 0.6145 & 0.1787 & 0.0364 & 1.0541 \\
\hline Male labor force in industry & 85 & 0.0577 & 0.0814 & 0.0015 & 0.6364 \\
\hline Female labor force in industry & 85 & 0.0362 & 0.0704 & 0.0001 & 0.5515 \\
\hline Male wage in agriculture & 86 & 1.4140 & 0.2872 & 0.7700 & 2.5200 \\
\hline Female wage in agriculture & 86 & 0.8917 & 0.1861 & 0.5500 & 1.6200 \\
\hline Male wage in industry & 86 & 2.2678 & 0.3847 & 1.5284 & 3.8263 \\
\hline Female wage in industry & 86 & 1.0798 & 0.1956 & 0.6480 & 1.6380 \\
\hline \multicolumn{6}{|l|}{ Education variables } \\
\hline Male literacy rate & 86 & 66.488 & 19.292 & 28.9 & 98.4 \\
\hline Female literacy rate & 86 & 49.527 & 23.839 & 15.9 & 95.4 \\
\hline Male enrollment in primary school & 86 & 0.5440 & 0.2113 & 0.1877 & 1.0594 \\
\hline $\begin{array}{l}\text { Female enrollment in primary } \\
\text { school }\end{array}$ & 86 & 0.3595 & 0.2586 & 0.0035 & 0.9965 \\
\hline Male public schools & 86 & 400.32 & 188.04 & 129 & 883 \\
\hline Female public schools & 86 & 109.47 & 91.044 & 2 & 508 \\
\hline \multicolumn{6}{|l|}{ Health variables } \\
\hline Male mortality & 86 & 0.0221 & 0.0027 & 0.0182 & 0.0298 \\
\hline Female mortality & 86 & 0.0221 & 0.0024 & 0.0168 & 0.0294 \\
\hline Boys' live births & 86 & 5774 & 3003 & 1991 & 21641 \\
\hline Girls' live births & 86 & 5519 & 2897 & 1943 & 20880 \\
\hline Male life expectancy at birth & 85 & 38.081 & 4.424 & 26.454 & 48.960 \\
\hline Female life expectancy at birth & 85 & 40.556 & 4.834 & 27.506 & 49.846 \\
\hline
\end{tabular}

Sources: Using data from Statistique Générale de la France.

female-to-male labor force ratio was markedly higher in agriculture (0.83) than in industry (0.48). To a lesser extent, the female-to-male average wage was higher in agriculture $(0.63)$ than in industry (0.47). However, both female and male average wages were substantially higher in industry than in agriculture; $1.08 \mathrm{~F}$ for women in industry as against $0.89 \mathrm{~F}$ in agriculture and $2.27 \mathrm{~F}$ for men in agriculture as against $1.41 \mathrm{~F}$ in agriculture.

Regarding educational variables, more than $66 \%$ of males and $50 \%$ of females in 1854 were able to read and write. In $1851,54.4 \%$ of boys but only $36 \%$ of girls aged 6-14 were enrolled in public primary schools. Across counties, there was strong heterogeneity in education: enrollment rates went from about 19\% (in Var) to $106 \%$ (in Manche) for boys and from 0.3\% (in Loir-Et-Cher) to 99\% (in Manche) for 
girls. ${ }^{9}$ These variations could result from several factors: the diffusion of the official French language, the difference in attitudes toward education between Catholics and Protestants [see Becker and Woessmann (2009)], the wave of ideas spreading from Prussia, and the insufficiency of the educational resources deployed in rural areas in terms of teachers and financial spending.

Finally, I turned to the health and survival variables. The data displayed highly similar mortality rates and numbers of live births between men and women. However, the data on life expectancy at birth showed that women lived on average two and a half years longer than men, i.e., for women, 40.5 years of life remained at age 0 . The health and survival data here displayed again great heterogeneity across France. Life expectancy at birth varied from 26.4 (in Seine) to 48.9 (in Gers) years for men and from 27.5 (in Seine) to 49.8 (in Orne) years for women, say, a difference of more than 22 years of life expectancy. ${ }^{10}$

The calculation of weights within each sub-index (step 3 of the methodology) is presented in Table 2. This procedure aimed to integrate the same relative impact on variables that had not reached similar levels of gender equality. This ensured that extra weight was not given to ratios displaying great heterogeneity across counties. Taking as a comparative example the female-to-male labor force in agriculture and in industry, we observe from Table 2 that the standard deviation of the ratio in agriculture is 0.12 and that of the ratio in industry is 0.34 . Accordingly, the female-to-male labor force participation in agriculture received a weight of 0.21 , while the female-to-male labor force participation in industry received a weight of 0.07 . Hence, in the construction of an economic opportunity sub-index, the labor force ratio in agriculture weighed more than the labor force ratio in industry. Comparatively, these variables weighed less than the wage ratios in agriculture and in industry, which presented weights of 0.35 and 0.37 , respectively.

This procedure was applied to each sub-index and its set of corresponding ratios. Accordingly, in the construction of the education sub-index, more weight was given to the public schools ratio and to the sex ratio at birth in the construction of the health and survival sub-index.

\section{The historical gender gap index in 1850s France}

\subsection{Geographic distribution of the index}

All counties in mid-nineteenth century France presented substantial gender inequalities. ${ }^{11}$ The average index was 0.71 but gender inequalities varied substantially

\footnotetext{
${ }^{9}$ In counties characterized by great investment in education, the enrollment rates can be greater than $100 \%$. The enrollment rate variable is built as the share of boys/girls enrolled in primary schools divided by the share of boys/girls belonging to the age group 5-15. Some children outside of this age category were also enrolled in primary education, explaining why some counties exhibit an enrollment rate above $100 \%$. Similar explanations apply to variables such as the labor force participation calculated as the number of working men/women belonging to the age group 15-60.

${ }^{10}$ This wide gap can be explained by the different levels of urbanization across counties. French county-level data suggest that large urban areas (such as Seine-characterized by a density of 29.9 people per $\mathrm{km}^{2}$ in 1851) displayed shorter life expectancy at birth than rural areas (such as Ornedisplaying a density of 0.72 people per $\mathrm{km}^{2}$ in 1851).

${ }^{11}$ Tables A.2 to A.5 in the Appendix provide the overall and sub-indices' scores of the 1850s gender gap index and their rankings for the 86 French counties. A map of administrative France with the name of the counties is presented as Figure A.1 in the Appendix.
} 
Table 2. Description of sub-indices and calculation of weights

\begin{tabular}{|c|c|c|c|}
\hline & $\begin{array}{l}\text { Standard } \\
\text { deviation }\end{array}$ & $\begin{array}{c}\text { Standard } \\
\text { deviation per } 1 \%\end{array}$ & Weights \\
\hline \multicolumn{4}{|l|}{ Economic opportunity } \\
\hline Female-to-male labor force in agriculture & 0.1163 & 0.0860 & 0.2052 \\
\hline Female-to-male labor force in industry & 0.3386 & 0.0295 & 0.0705 \\
\hline Female-to-male wage in agriculture & 0.0681 & 0.1469 & 0.3505 \\
\hline Female-to-male wage in industry & 0.0639 & 0.1566 & 0.3737 \\
\hline Total & & 0.4189 & 1 \\
\hline \multicolumn{4}{|l|}{ Educational attainment } \\
\hline Female-to-male literacy rate & 0.1870 & 0.0534 & 0.3111 \\
\hline $\begin{array}{l}\text { Female-to-male enrollment in primary } \\
\text { school }\end{array}$ & 0.2637 & 0.0379 & 0.2633 \\
\hline Female-to-male public schools & 0.1899 & 0.0527 & 0.3656 \\
\hline Total & & 0.1440 & 1 \\
\hline \multicolumn{4}{|l|}{ Health and survival } \\
\hline Female-to-male life expectancy at birth & 0.0464 & 0.2156 & 0.2818 \\
\hline Female-to-male mortality (reversed) & 0.0507 & 0.1970 & 0.2575 \\
\hline Female-to-male living births & 0.0284 & 0.3525 & 0.4607 \\
\hline Total & & 0.7651 & 1 \\
\hline
\end{tabular}

between counties. The index ranged from 0.58 (Pyrénées Orientales) to 0.86 (Mayenne). In particular, Northern counties were the counties with the narrowest gender gap (Mayenne, Manche, Vosges, Seine-Inférieure, Haut-Rhin, Sarthe, and Seine). The gap between women and men was lower in terms of health and survival outcomes (0.99 on average) than in educational attainment (0.52) and economic opportunities (0.60). But here again wide disparities between counties existed. Differences between counties in the educational attainment gap could be extreme: Mayenne records 0.929 while Corse is only about 0.18 . The size of the gap in economic opportunities was more than 1.6 times as big in Drôme as it was in Bouches-du-Rhône.

Figure 1 presents the geographical distribution of the 1850s gender gap index. The mapping enables us to identify the strengths and weaknesses of all the French regions. The map reveals two areas, separated by an imaginary arc going from Vendée to Drôme. In the Northeastern part of the arc, counties perform better than in the Southwestern part of the arc, where the counties display large gender disparities. A clear regional divide appears in the same figure. ${ }^{12}$ Northeastern France holds the top position of gender parity, closely followed by the Northwestern regions, where over 77\% of the gender gap was closed. Next come Northern France and the Paris Basin region, which closed on average $74 \%$ of the gender gap, and east-central France with $72 \%$. Southwestern and Central France and the Mediterranean periphery, however, display

\footnotetext{
${ }^{12}$ See Figure A.3 in the Appendix for a graphic illustration of regional performances for each indicator.
} 


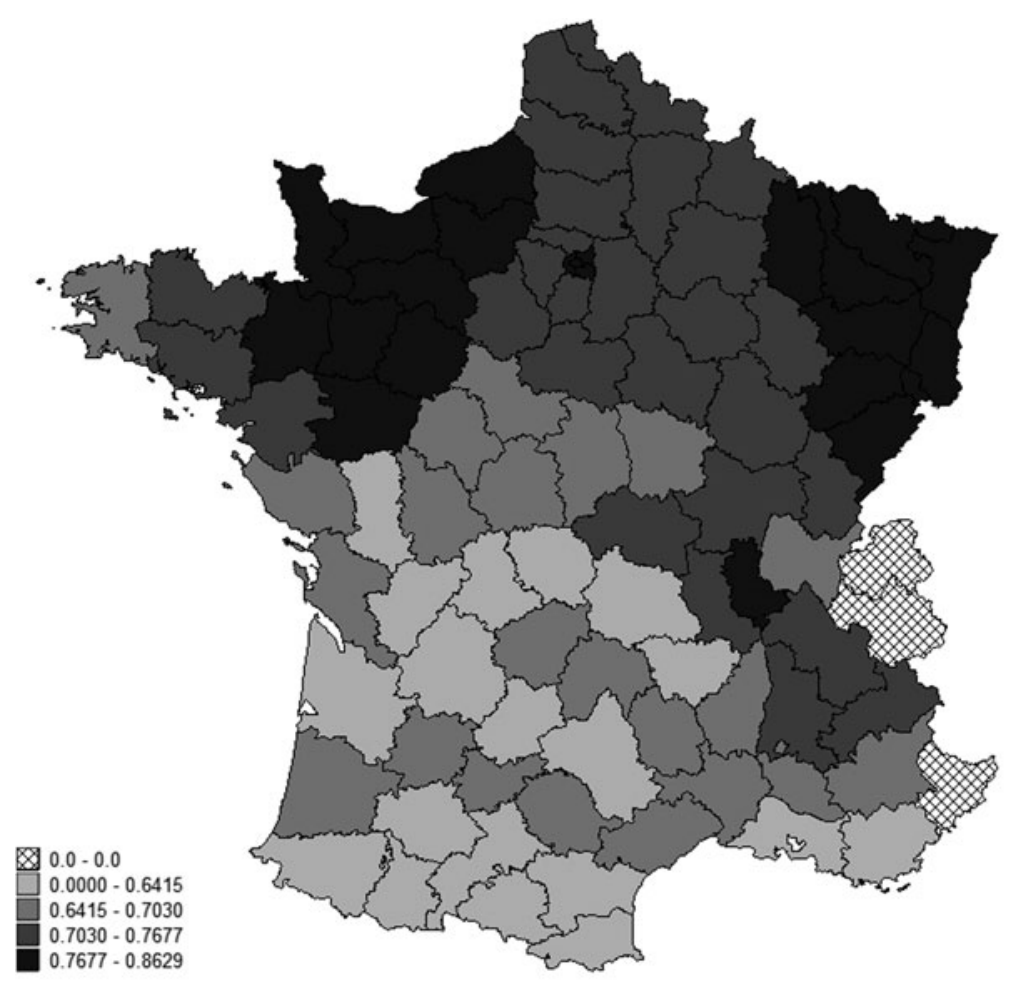

Figure 1. Geographical distribution of the 1850s gender gap index. Sources: Using data from Statistique Générale de la France.

higher gender disparities, having closed less than $64 \%$ of their gender gap. A closer look at the sub-indices shows that the education sub-index was the main determinant of the variations observed across the territory. Regions located in the upper part of the imaginary arc, namely, northern France, held the top rankings thanks to their high performance in the educational attainment sub-index. These regions also appeared to score better in economic participation and opportunities. Yet the global spread of regional heterogeneity remains much lower for the economic sub-index than for the education sub-index.

Regions located in the lower part of the imaginary arc-the Mediterranean periphery, the Center, and the Southwestern regions-lagged behind in the overall ranking. A few counties-Ariège, Gers, Haute-Loire, Pyrénées-Orientales, Lot, and Corse-were widely penalized because of their low scores in educational attainment. Counties located in this region on average closed less than $34 \%$ of the gender gap in education. Counties located on the Mediterranean periphery and the Atlantic coast (except the Landes) scored lower in economic opportunities and participation than other counties. As far as the health and survival sub-index is concerned, counties belonging to the central part of the Atlantic coast presented lower scores than the rest of France, with Charente, Deux-Sèvres, and Indre at the lower end of the rankings. 
Table 3. Correlation matrix

\begin{tabular}{lccc}
\hline & Gender gap index & Education sub-index & Economic sub-index \\
\hline Education sub-index & 0.9672 & - & - \\
\hline Economic sub-index & 0.5581 & 0.3588 & - \\
\hline Health sub-index & 0.3267 & 0.0666 & 0.2248 \\
\hline
\end{tabular}

The correlation matrix confirms the importance of the education sub-index for understanding the distribution of the main strengths and weaknesses of France across its territory. Table 3 presents the correlation coefficients between the overall index and its sub-indices. The education sub-index stood as the most closely correlated component. It correlated at 0.97 with the overall index, while the economic sub-index correlated at 0.56 , and the health sub-index at $0.33 .{ }^{13}$

\subsection{Determinants of the index}

The index measures gender-based differences in the outcome variables. This provided an index a priori independent of the level of development of the counties, which allowed the analysis to extend to the possible factors (county-specific input variables) that explain the extent of the gender gaps. The aim of this sub-section is to identify the key determinants of the gender gap index.

\subsubsection{Empirical strategy}

I estimated the following equation using OLS estimators:

$$
G G I_{i, 1850 s}^{k}=\beta_{0}+\beta_{1} X_{i, 1850 s}^{j}+\epsilon_{i}
$$

where $i$ stands for county $i$; $k$ refers to my measures of gender equality (overall index and sub-indices); $j$ represents the gender. $X_{i}^{j}$ includes a set of explanatory variables at the county level. The $\beta$ coefficients are my parameters of interest. $\epsilon_{i}$ is the error term.

I successively ran the regression using the overall index and its sub-indices (education, economic, health) to explore the importance of potential covariates of interest. The following set of variables of interest was used in the regression analysis: (i) I accounted for education using girls' and boys' enrollment rates in public primary schools; (ii) women's and men's labor force participation in agriculture and in industry was used to account for the occupational structure and job opportunities for men and women; (iii) women's and men's wages in agriculture and in industry were integrated to capture the access to resources and income opportunities; (iv) the density and level of urbanization, respectively, constructed as the number of individuals per square meter and the share of individuals living in towns with more than 2,000 inhabitants; all these variables were used to account for the possibility of greater access to opportunities in highly densely and urbanized areas; (v) the share of married women was used as a complementary factor to capture women's agency and a possible gendered division of the tasks between the family sphere and the professional sphere; (vi) the number of individuals per house was used as a measure

\footnotetext{
${ }^{13}$ Figure A. 2 in the Appendix presents the graphic illustration of the information in column 1 of Table 3.
} 
capturing the existence of complex households where several generations live under the same roof and complementarily reflecting the existence of a greater number of children living in the household. ${ }^{14}$

Because of multicollinearity issues, I ran separate regressions using gendered-specific covariates. The odd columns report the results of the regressions accounting for information about girls' education, women's occupational structure, and women's wages, as covariates. The even columns report the results of the regressions using boys' education, men's occupational structure, and men's wages, as covariates. The share of married women is included both in odd and even columns. The remaining variables-density, urban residents, and individuals per house-concern the general population and are controlled for in all columns.

\subsubsection{Overall index}

Table 4 reports the OLS estimates of the association between the gender gap index and sub-indices and the set of explanatory variables. The use of standardized coefficients enables us to compare the relative importance of each coefficient. Columns 1 and 2 present the results using the overall index as my dependent variable. Education for girls as well as for boys stands out as incremental determinants. An increase of one standard deviation in girls' enrollment in public primary education resulted in an increase by 0.78 standard deviations in the gender gap index (column 1). In a smaller order of magnitude, a unit increase in the boys' enrollment rate resulted in 0.54 units in the gender gap index.

As far as the occupational structure was concerned, the female labor force participation, both in agriculture and in industry, presented a positive association with the gender gap index, to the greater magnitude of the latter. The model shows that an increase of one standard deviation in the participation of the female labor force in industry was associated with a rise by 0.16 standard deviations of the index, at the $5 \%$ probability level. By comparison, the participation of the male labor force in agriculture was negatively and insignificantly associated. The male labor force participation in industry, however, exhibited a strong and significant positive association with the index. An increase of one standard deviation in the participation of the male labor force in industry was associated with a rise by 0.30 standard deviations of the index, at the $0.1 \%$ probability level. Hence, the regions characterized by a dynamic industrial sector that hired high shares of men and women displayed greater overall gender equality.

Findings about women's wages in industry confirm the importance of the industrial sector for understanding the distribution of gender equality across France. An increase of one standard deviation in women's wages in industry was positively and significantly associated with an increase by 0.23 standard deviations in gender equality level. More densely populated and urbanized areas-where industries were more likely to develop and proper-presented similar positive associations.

Family constraints seemed, however, to affect the index negatively. The share of married women was the most glaring factor. An increase of one standard deviation in the share of married women was significantly (at the $0.1 \%$ probability level) associated with a decrease by 0.25 standard deviations in gender equality. Family life appeared to act as a factor pulling down the position of women within the household and more generally in society. In a similar line in interpretation, the share

\footnotetext{
${ }^{14}$ The descriptive statistics of the variables used in the regression that do not appear in Table 1 are reported in Table B.1 of the Appendix.
} 
Table 4. OLS estimates: determinants of the gender gap and sub-indices

\begin{tabular}{|c|c|c|c|c|c|c|c|c|}
\hline \multirow[b]{2}{*}{ Dependent variable } & \multicolumn{2}{|c|}{ GGI-overall } & \multicolumn{2}{|c|}{ GGI-education } & \multicolumn{2}{|c|}{ GGI-economic } & \multicolumn{2}{|c|}{ GGI-health } \\
\hline & (1) Women & (2) Men & (3) Women & (4) Men & (5) Women & (6) Men & (7) Women & (8) Men \\
\hline \multirow[t]{2}{*}{ Public enrollment } & $0.777^{\star \star \star}$ & $0.543^{\star \star \star}$ & $0.807^{\star \star \star}$ & $0.543^{\star \star \star}$ & $0.296^{*}$ & 0.249 & 0.106 & 0.151 \\
\hline & $(0.023)$ & $(0.043)$ & $(0.060)$ & $(0.113)$ & $(0.031)$ & $(0.047)$ & $(0.015)$ & $(0.022)$ \\
\hline \multirow[t]{2}{*}{ LFP in agriculture } & $0.138^{\star}$ & -0.096 & 0.044 & -0.154 & $0.525^{\star \star \star}$ & 0.181 & -0.023 & -0.066 \\
\hline & $(0.026)$ & $(0.053)$ & $(0.063)$ & $(0.140)$ & $(0.033)$ & $(0.046)$ & $(0.018)$ & $(0.021)$ \\
\hline \multirow[t]{2}{*}{ LFP in industry } & $0.161^{*}$ & $0.304^{\star \star \star}$ & 0.084 & $0.228^{\star \star}$ & 0.306 & $0.352^{\star \star \star}$ & 0.119 & $0.185^{*}$ \\
\hline & $(0.064)$ & $(0.077)$ & $(0.112)$ & $(0.190)$ & $(0.115)$ & $(0.062)$ & $(0.025)$ & $(0.024)$ \\
\hline \multirow[t]{2}{*}{ Wages in agriculture } & -0.050 & -0.152 & -0.112 & -0.155 & 0.091 & 0.108 & -0.119 & $-0.381^{*}$ \\
\hline & $(0.033)$ & $(0.033)$ & $(0.089)$ & $(0.079)$ & $(0.034)$ & $(0.035)$ & $(0.020)$ & $(0.014)$ \\
\hline \multirow[t]{2}{*}{ Wages in industry } & $0.232^{\star \star \star}$ & 0.098 & $0.194^{\star \star}$ & 0.181 & $0.264^{\star}$ & -0.035 & 0.008 & 0.154 \\
\hline & $(0.024)$ & $(0.024)$ & $(0.061)$ & $(0.059)$ & $(0.026)$ & $(0.024)$ & $(0.019)$ & $(0.011)$ \\
\hline \multirow[t]{2}{*}{ Density } & $0.584^{\star \star}$ & $0.670^{\star \star}$ & $0.526^{\star \star}$ & $0.657^{\star \star}$ & 0.216 & 0.290 & 0.365 & 0.299 \\
\hline & $(0.004)$ & $(0.005)$ & $(0.010)$ & $(0.012)$ & $(0.005)$ & $(0.006)$ & $(0.002)$ & $(0.002)$ \\
\hline \multirow[t]{2}{*}{ Urban residents } & $0.260^{\star \star}$ & 0.127 & $0.271^{\star \star}$ & 0.130 & 0.120 & 0.037 & -0.009 & 0.05 \\
\hline & $(0.039)$ & $(0.057)$ & $(0.101)$ & $(0.153)$ & $(0.049)$ & $(0.052)$ & $(0.023)$ & $(0.022)$ \\
\hline \multirow[t]{2}{*}{ Share married women } & $-0.248^{\star \star \star}$ & -0.181 & $-0.158^{\star}$ & -0.132 & $-0.359^{\star \star \star}$ & -0.247 & -0.208 & -0.064 \\
\hline & $(0.082)$ & $(0.137)$ & $(0.233)$ & $(0.360)$ & $(0.082)$ & $(0.124)$ & $(0.047)$ & $(0.060)$ \\
\hline \multirow[t]{2}{*}{ Individuals per house } & $-0.483^{*}$ & $-0.544^{\star}$ & $-0.430^{\star}$ & $-0.550^{\star}$ & -0.245 & -0.153 & -0.456 & -0.294 \\
\hline & $(0.006)$ & $(0.008)$ & $(0.016)$ & $(0.021)$ & $(0.007)$ & $(0.008)$ & $(0.003)$ & $(0.003)$ \\
\hline
\end{tabular}


Table 4. (Continued.)

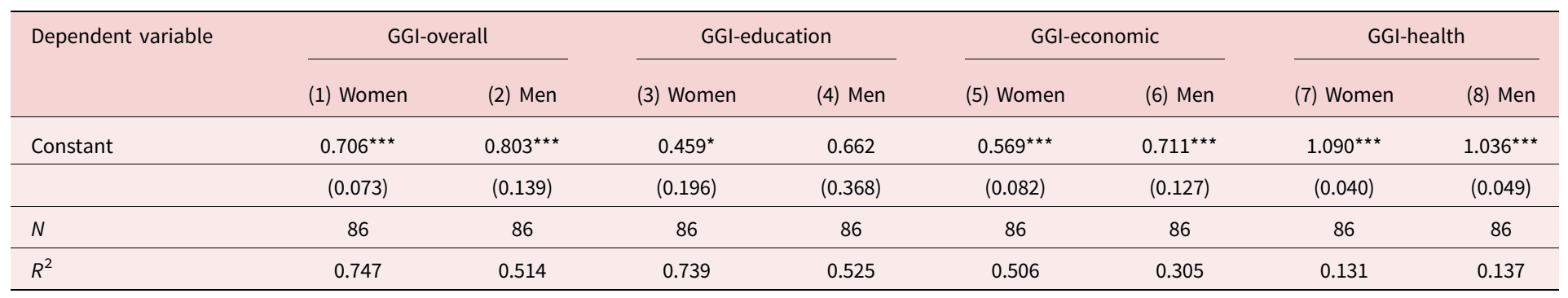

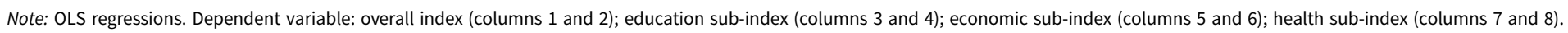
Odd columns report the results using information about girls/women as covariates. Even columns report the results using information about boys/men as covariates. Standardized $\beta$ coefficients. Robust standard errors in parentheses. ${ }^{\star} p<0.05,{ }^{\star *} p<0.01,{ }^{\star \star *} p<0.001$.

Source: County-level data from the Statistique Générale de la France. 
of individuals per house, reflecting the degree of complexity of the household, confirmed the existence of a negative and significant association between the size of the family and the level of gender equality.

\subsubsection{Sub-indices}

The remaining columns of Table 4 report the OLS estimates of equation (1) using the sub-indices in turn as dependent variables. Columns 3, 5, and 7 present the standardized coefficients when using information about girls/women as covariates. Columns 4, 6, and 8 display the coefficients when using information about boys/ men, as covariates. The factors determining the distribution of the sub-indices, and accordingly their underlying mechanisms, may differ from one sub-index to another.

The crucial determinants of the education sub-index are unsurprisingly the enrollment rates in primary education. An increase by one standard deviation in girls' and boys' education was significantly correlated with an increase by 0.81 and 0.54 standard deviations, respectively, in the education sub-index. By order of magnitude, the density, the number of individuals per house, the male labor force in industry, the female wage in industry, and the share of married women stood as the major additional and decisive factors of the geographic distribution of the gender gap in education. While the male labor force in industry and the female wage in industry were both positively associated with greater equality in education (at the $1 \%$ probability level), the share of married women and the number of individuals per house were negatively associated (at the $5 \%$ probability level).

As far as the economic sub-index was concerned, if girls' education remained positively associated with gender equality, the significance and magnitude of the association substantially decreased and the association with boys' education disappeared completely. The participation of the male labor force in industry, together with the female labor force in agriculture and the share of married women, was the most discriminatory factor. ${ }^{15}$ An increase of one standard deviation in the male labor force participation in industry was associated with an increase by 0.35 standard deviation in the economic sub-index, while an increase of one standard deviation in the share of married women was associated with a decrease by 0.36 standard deviation in the sub-index. In line with Galor and Weil (1996), women's wages in industry are significantly associated with greater gender equality.

The health sub-index was weakly associated with the various determinants investigated in the model. With the exception of the participation of the male labor force in industry, which was positively associated with the sub-index and the male wage in agriculture, which was negatively associated, both at the $5 \%$ probability level, none of the remaining variables correlated with the health sub-index. ${ }^{16}$

\footnotetext{
${ }^{15}$ Looking at US and cross-country data, Goldin $(1990,1994)$ has shown that the labor force participation of (married) women followed a U-shaped trajectory alongside economic development. The movement of women from the home to the workplace is argued to have promoted various types of gender equality both in society and in the home.

${ }^{16}$ If most of the determinants tested did not correlate with the health sub-index, their effect on health variables in levels was likely to have an explanatory power, rather than ratios. Additional regressions that were run using additional potential determinants more directly connected to the health and survival criteria presented similar insignificant associations with the health sub-index.
} 


\subsubsection{Patriarchy, culture, and norms}

The investigation conducted above, which estimated the explanatory power of a set of variables, revealed a number of interesting findings. It suggested the existence of powerful interactions between women's access to economic opportunities and resources, family structure and organization, and the relative status of women.

Gender equality undoubtedly depends on the cultural context. The family, as a universal social institution, is the primary place of socialization and of the transmission of values, norms, and beliefs. Family organization is not homogeneous and may differ from one family to another. The distribution of activities between the members of the household, namely, between the public/professional sphere (economic activities) and the family sphere (domestic activities, care of the offspring/ elderly), depends on the family structure. Certain family structures favor gender equality more than others. The degree of women's autonomy differs according to the type of family.

The family systems can be divided into two major groups: the nuclear family (consisting of two parents and their children) and the extended family (the parents, their children, and members of their extended family). Todd (1990, 2011) classified family systems into subcategories depending on the degrees of liberty/authority (between parents and children) and equality/inequality (between siblings). Accordingly, Todd identified a range of traditional family types that could be split into five main categories: nuclear egalitarian, nuclear absolute, communitarian, stem, and cooperative. ${ }^{17}$ As their names imply, the first two of his family types belong to the category of nuclear family. The remainder share the characteristics of the extended family type. ${ }^{18}$

The structure of households is not uniform across France. Table 5 presents the coefficients of the family types (in comparison to the communitarian type). The results are presented using first the overall index (column 1) and then the sub-indices (columns 2-4). A clear divide appears between the nuclear family types and the extended family types. The results show positive and significant associations (at the $0.1 \%$ probability level) with nuclear families-egalitarian and absolute-and no or negative associations with extended families-stem and cooperative. Similar associations were found with higher magnitude when using the education sub-index and with lower magnitude when using the economic sub-index. Women in the nuclear family category seem to enjoy a higher position and degree of autonomy than women in the extended family types, where the distribution of activities appeared, as ever, to be highly segregated by gender.

\footnotetext{
${ }^{17}$ Todd refined his classification over time. The number of family types identified by Todd across France evolved from three family types up to nine in a synthesis of his work published in a book co-written with Le Bras. In order to have a suitable number of observations per type of family for estimation, I followed the same strategy as the one used by Diebolt et al. (2017) by grouping the nine types [see figure 1-4 in Le Bras and Todd (2013)] into five relevant categories [consistent with Todd's (1990) earlier classification and taking into account the refinement made by Todd's latest classification].

${ }^{18}$ Absolute and egalitarian nuclear families, characterized by the total emancipation of children in their adulthood, differ from each other with regard to inheritance rules. In absolute families, inheritance goes to one child alone (often the son), while in egalitarian families, inheritance is equally divided between the offspring. Intermediate/Communitarian families are extended families in which all the sons can get married and bring their wives to the family home. In stem families, several generations live under the same roof. Usually, the oldest child inherits the house and lands, to preserve the lineage. Cooperative families are characterized by equality in inheritance among the (male) offspring.
} 
Table 5. OLS estimates: family structures

\begin{tabular}{|c|c|c|c|c|}
\hline \multirow[b]{2}{*}{$\begin{array}{l}\text { Family types (vs. } \\
\text { intermediate) }\end{array}$} & \multicolumn{4}{|c|}{ Dependent variable } \\
\hline & $\begin{array}{c}(1) \\
\text { GGI-overall }\end{array}$ & $\begin{array}{c}(2) \\
\text { GGI-education }\end{array}$ & $\begin{array}{c}(3) \\
\text { GGI-economic }\end{array}$ & $\begin{array}{c}\text { (4) } \\
\text { GGI-health }\end{array}$ \\
\hline \multirow[t]{2}{*}{ Nuclear egalitarian } & $0.085^{\star \star \star}$ & $0.215^{\star \star \star}$ & $0.026^{\star}$ & 0.014 \\
\hline & $(0.012)$ & $(0.029)$ & $(0.013)$ & $(0.008)$ \\
\hline \multirow[t]{2}{*}{ Nuclear absolute } & $0.132^{\star \star \star}$ & $0.329^{\star \star \star}$ & $0.048^{\star \star}$ & 0.018 \\
\hline & $(0.02)$ & $(0.056)$ & $(0.016)$ & $(0.01)$ \\
\hline \multirow[t]{2}{*}{ Stem } & 0.006 & -0.012 & 0.025 & 0.005 \\
\hline & $(0.016)$ & $(0.041)$ & $(0.014)$ & $(0.009)$ \\
\hline \multirow[t]{2}{*}{ Cooperative } & $-0.048^{\star}$ & -0.086 & $-0.055^{\star}$ & -0.004 \\
\hline & $(0.018)$ & $(0.053)$ & $(0.023)$ & $(0.01)$ \\
\hline \multirow[t]{2}{*}{ Constant } & $0.671^{\star \star \star}$ & $0.439^{\star \star \star}$ & $0.591^{\star \star \star}$ & $0.984^{\star \star \star}$ \\
\hline & $(0.009)$ & $(0.024)$ & $(0.009)$ & $(0.007)$ \\
\hline$N$ & 87 & 87 & 87 & 87 \\
\hline$R^{2}$ & 0.546 & 0.538 & 0.228 & 0.077 \\
\hline
\end{tabular}

Note: OLS regressions. Dependent variable: overall index (columns 1); education sub-index (columns 2); economic sub-index (column 3); health sub-index (column 4). The reference category is the intermediate family. Robust standard errors in parentheses ${ }^{\star} p<0.05,{ }^{\star \star} p<0.01,{ }^{\star \star \star} p<0.001$.

Source: See description in the text.

The analysis conducted in sub-section 4.2 aimed at investigating the role of a set of potential determinants of my gender index. My results reveal the importance of the industrial sector, of investments in education, as well as the importance of cultural factors for understanding the distribution of gender equality across the French territory in the mid-nineteenth century. Counties characterized by greater education for boys and girls, dynamic industries employing high shares of female and male workers, and offering women access to well-paid jobs displayed higher levels of gender equality. The possibility for women to be employed and receive fair payment for their work enabled women to gain autonomy, which may have resulted in greater independence for women in the decision-making process.

My results confirmed the evidence from analyzing contemporaneous data: that women's access to education can bring essential changes [see Jejeebhoy (1995)]. Beyond gaining access to new knowledge, girls may access wider job opportunities and earn their living, develop the capacity to question, reflect, and act on the conditions of their lives. Women's empowerment contributes to fostering the spread of new ideas. Moreover, my results suggest that not only does girls' education matter for gender equality but that boys' education is also incremental.

Additional results show that for women being married is negatively associated with their autonomy. Counties where the share of married women was higher displayed lower scores on the various dimensions of gender equality. Women seemed to have more control over their lives in regions where proportionally fewer married. Investigating the association between gender equality and family structures revealed that nuclear family types displayed greater gender equality than extended family types. 


\section{Gender equality and economic growth}

How far can heterogeneity in gender inequalities across France contribute to understand the variations in economic performance and their distribution across the territory? The previous section examined the amplitude and geographical distribution of the gender gap index in France in the 1850s and highlighted a set of important determinants of gender equality. In this section, I report the use made of the index and sub-indices to assess whether or not lower gender inequalities were associated with better performances, as predicted by the theoretical unified growth model developed by Diebolt and Perrin (2013, 2019).

\subsection{Empirical analysis}

First, I present the scatter plot (Figure 2) that relates the gender gap index with the gross value added per capita in 1860 at the county level. A positive correlation appears between the extent of gender equality and economic performance. This means that counties with a higher gender gap index were likely to have had a higher gross value added per capita. Gender equality may have affected economic growth through various channels, such as the quality of endowments in human capital, the allocation of talent across occupations, and the level of consumption.

Second, I tested the following equation using OLS estimators:

$$
\text { Economic_Performance }_{i, 1860}=\beta_{0}+\beta_{1} G G I_{i, 1850 s}^{k}+\beta_{2} X_{i, 1850 s}+\epsilon_{i} \text {, }
$$

where $i$ stands for the French county; $k$ refers to the measures of gender equality, i.e., overall index and sub-indices; $X_{i}$ denotes the vector of the control variables; and $\epsilon_{i}$ is the error term. Economic_Performance $e_{i}$ is captured by the Gross value added per capita measured in 1860 .

$X_{i}$ includes controls at the county level, constructed on the basis of information from French Censuses of the 1850s, which reduce unobserved heterogeneity across counties. First, I accounted for fertility measures, namely, the child-women ratio (the number of children aged $0-5$ per woman of childbearing age) and the female (median) age at marriage. Second, I controlled for infant mortality, used as a proxy for health and as a determinant of the gross potential. Third, the population density was added to equation (2) to proxy the extent of urbanization and control for dynamic gains emerging from growing cities through increasing the accumulation of human capital [Bertinelli and Black (2004)]. Fourth, I controlled for inequality in land ownership. Landowners delay the development of the industrial sector and of possible income growth because they have little interest in public schooling, given the low complementarity between land and human capital [Galor et al. (2009)]. To measure gender equality, I tested equation (2) using as alternatives the overall gender gap index, the education sub-index, the economic sub-index, and the health sub-index.

\subsection{Findings}

OLS estimates of equation (2) are reported in Table 6. Column 1 presents the results using the overall gender gap index as the variable of interest. A higher GGI, namely greater gender equality, was found to be significantly and positively correlated with higher economic performance. An increase of one standard deviation in the gender index was associated with an increase by 0.30 standard deviations in the gross value 


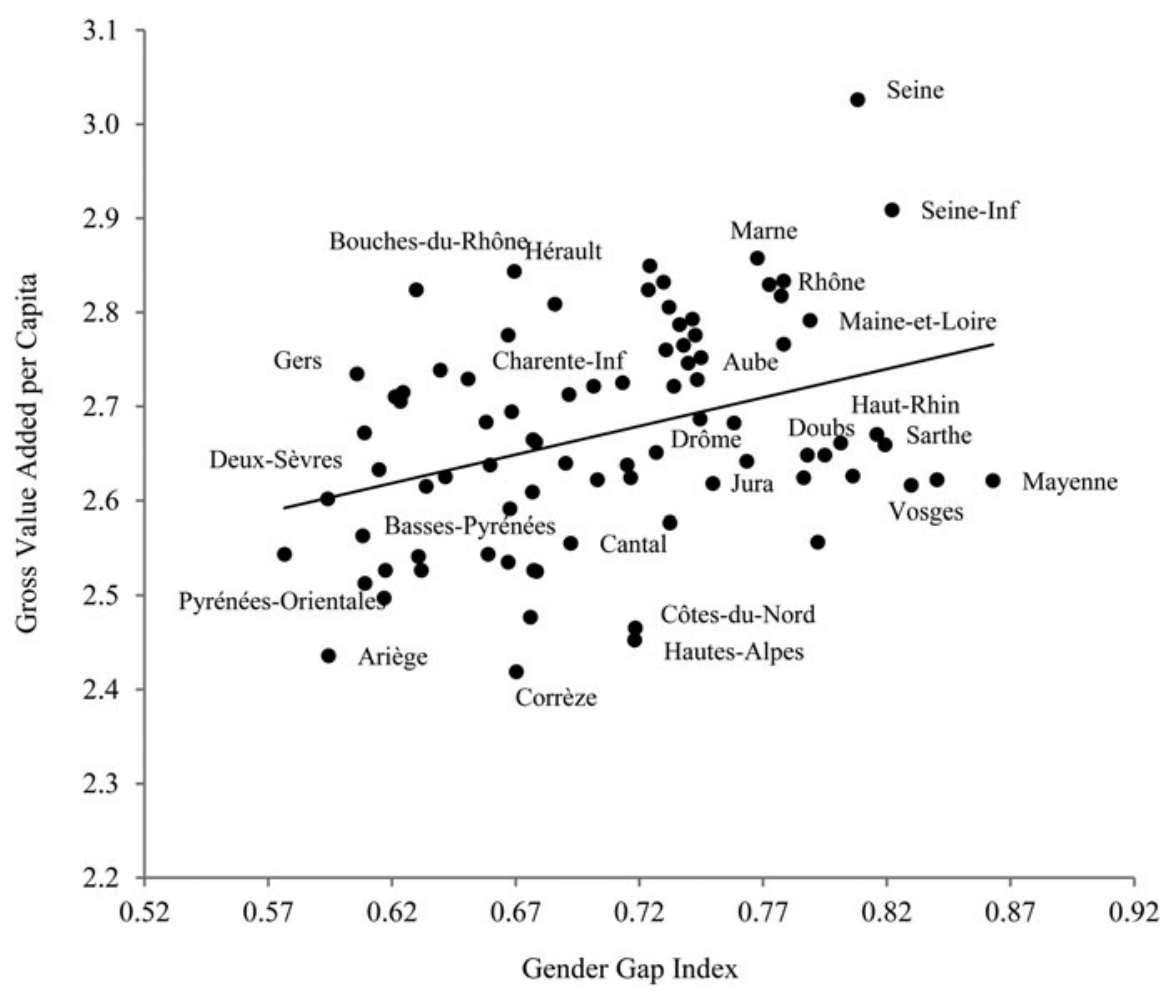

Figure 2. Scatter plot of the links between GGI and economic performance.

Source: Using data from Caruana-Galizia (2013) and Statistique Générale de la France.

added per capita, at the $0.1 \%$ probability level. This positive association provided preliminary support to the theoretical predictions that empowering women benefits economic growth [Diebolt and Perrin $(2013,2019)$ ].

The economic performance of a county can be affected by a range of additional factors likely to explain the heterogeneity observed across France. Controlling for demographic variables revealed interesting findings in line with the key predictions of unified growth models and related literature [Galor and Weil (1999, 2000), Galor and Moav (2002), Doepke (2004)]. Lower fertility rates were significantly correlated with higher economic performance (at the $0.1 \%$ percentage level). An increase of one standard deviation in the number of children per woman was associated with a decrease by 0.31 standard deviations in the gross value added. This result was in line with the idea that the demographic transition had a powerful impact on economic growth [Bloom and Williamson (1998)]. The data also confirm that health conditions, proxied by the infant mortality rate, were negatively and significantly associated (at the 5\% probability level) with the economic performance of the county. According to Bloom et al. (2004), this negative association could have occurred through lower labor productivity.

A counterintuitive result was the negative association between the female median age at marriage and the gross value added per capita. Age at first marriage is sometimes interpreted as a measure of a woman's bargaining power (Maubrigades, 2015) and is 
Table 6. OLS estimates of gross value added per capita

\begin{tabular}{|c|c|c|c|c|}
\hline \multirow[b]{2}{*}{ Dependent variable } & \multicolumn{2}{|c|}{ Gross value added per capita } & \multirow[b]{2}{*}{ (3) GGI-economic } & \multirow[b]{2}{*}{ (4) GGI-health } \\
\hline & (1) GGI-overall & (2) GGI-education & & \\
\hline \multirow[t]{2}{*}{ Gender gap index } & $0.302^{\star \star \star}$ & $0.359^{\star \star \star}$ & 0.072 & -0.099 \\
\hline & $(0.169)$ & $(0.065)$ & $(0.211)$ & $(0.425)$ \\
\hline \multirow[t]{2}{*}{ Child-women ratio } & $-0.313^{\star \star \star}$ & $-0.320^{\star \star \star}$ & $-0.295^{\star \star \star}$ & $-0.293^{\star \star \star}$ \\
\hline & $(0.140)$ & $(0.136)$ & $(0.151)$ & $(0.150)$ \\
\hline \multirow[t]{2}{*}{ Infant mortality } & $-0.184^{\star}$ & $-0.178^{\star}$ & $-0.202^{\star}$ & $-0.209^{\star}$ \\
\hline & $(0.135)$ & $(0.131)$ & $(0.145)$ & $(0.145)$ \\
\hline \multirow[t]{2}{*}{ Female age at marriage } & $-0.322^{\star \star \star}$ & $-0.329^{\star \star \star}$ & $-0.219^{\star \star}$ & $-0.178^{\star}$ \\
\hline & $(0.008)$ & $(0.008)$ & $(0.008)$ & $(0.008)$ \\
\hline \multirow[t]{2}{*}{ Landownership inequality } & $-0.297^{\star \star \star}$ & $-0.258^{\star \star}$ & $-0.413^{\star \star \star}$ & $-0.432^{\star \star \star}$ \\
\hline & $(0.060)$ & $(0.060)$ & $(0.060)$ & $(0.061)$ \\
\hline \multirow[t]{2}{*}{ Density } & $0.388^{\star \star \star}$ & $0.362^{\star \star \star}$ & $0.437^{\star \star \star}$ & $0.430^{\star \star \star}$ \\
\hline & $(0.003)$ & $(0.003)$ & $(0.004)$ & $(0.004)$ \\
\hline \multirow[t]{2}{*}{ Constant } & $0.302^{\star \star \star}$ & $0.359^{\star \star \star}$ & 0.072 & -0.099 \\
\hline & $(0.169)$ & $(0.065)$ & $(0.211)$ & $(0.425)$ \\
\hline$N$ & 84 & 84 & 84 & 84 \\
\hline$R^{2}$ & 0.634 & 0.655 & 0.577 & 0.581 \\
\hline
\end{tabular}

Note: OLS regressions. Dependent variable: gross value added per capita in 1860. Variable of interest: overall index (column 1); education sub-index (column 2); economic sub-index (column 3); health sub-index (column 4). Standardized $\beta$ coefficients. Standard errors in parentheses. ${ }^{\star} p<0.05,{ }^{\star \star} p<0.01,{ }^{\star \star *} p<0.001$.

Source: County-level data from the Statistique Générale de la France.

used as an indicator of female agency [Carmichael (2011)]. In the case of nineteenth-century France, as shown by Perrin and Benaim's (2019) typology, progressive counties that economically performed best were characterized by high levels of gender equality, low fertility, high enrollment rates for boys and girls, and younger age at marriage. This might mean that people could afford to marry sooner if they or their families were already prosperous. As argued by Perrin and Benaim (2019), young age at marriage in the context of nineteenth century France could also reflect the higher degree of agency (greater bargaining power in the decision-making process) that women enjoyed within the family.

As expected, counties with lower shares of landowners displayed lower gross value added per capita. An increase of one standard deviation in landownership inequality was associated with a decrease by 0.30 standard deviations in gross value added. This result confirmed the theoretical predictions of Galor et al. (2009) that inequality in the distribution of landownership played a significant role in the emergence of sustained differences in human capital formation and growth patterns across economies. My estimates also confirmed that the more densely populated areas were significantly associated with better economic performance. 
The same analysis was conducted using all the sub-indices in succession. Even if the associations found for the control variables remained unchanged (with similar magnitude and significance), the sub-indices presented different results. As far as the education sub-index was concerned (column 2), the positive and significant association was confirmed. ${ }^{19}$ An increase of one standard deviation in gender equality in education was positively and significantly associated with an increase by 0.36 standard deviations in economic performance. This positive association supports the theoretical argument that greater gender equality in human capital is beneficial for economic growth [Lagerlöf (2003)]. The economic and health sub-indices (columns 3 and 4, respectively), however, showed insignificant effects on economic performance.

Education appeared as a decisive factor in fostering gender equality (Table 4). The importance of education is confirmed by the coefficients presented in Table 6. Looking at the effect on economic performance of the gender gap index separately from the effects of its sub-indices, it emerged that the explanatory power of the overall index is mostly triggered by the education sub-index. This finding suggests that education is a crucial factor to improve overall gender equality and that gender equality-in particular gender equality in education-is crucial to foster economic growth.

\subsection{Robustness check}

The findings may have been driven by the variable chosen to measure economic performance. I therefore tested the sensitivity of the results using alternative measures of the dependent variable. I successively employed GDP per capita, manufacturing output, horse power per capita, proto-industrialization, and GVA per capita in 1886 and also in 1901, as alternative measures to economic performance. ${ }^{20}$

The positive and significant association found in Table 6 holds for all the alternative measures of economic performance. These results confirm the existence of a robust and significant association between gender equality and economic growth (Table 7).

The analysis conducted in section 5 empirically confirmed the close association between gender equality and economic growth. It also showed the usefulness of accounting for the multiple dimensions of gender equality. My results suggest that efforts to foster gender equality and boost economic growth need to be made within the overall spectrum of gender equality. As shown in the analysis conducted in sub-section 4.2, education appeared incremental for doing so.

\section{Conclusion}

The primary contribution of this paper is the construction of a gender gap index at the historical level. This paper is the first attempt to capture the multi-dimensional aspects of gender equality in the past-during a critical period of France's process of economic and demographic development. My ambition with the construction of such an index was to provide a comprehensive measure of gender equality, easily comparable with other variables, i.e., economic, demographic, or cultural, from a historical perspective,

\footnotetext{
${ }^{19}$ This result corroborates the importance of the gender gap in education shown by the literature [see Bertocchi and Bozzano (2019), for a comprehensive review of the literature on the subject].

${ }^{20}$ The description of the variables and summary statistics are provided in Appendix B.
} 
Table 7. Alternative measures of economic performance

\begin{tabular}{|c|c|c|c|c|c|c|}
\hline $\begin{array}{l}\text { Dependent } \\
\text { variable }\end{array}$ & $\begin{array}{c}\text { GDP per } \\
\text { capita } \\
(1)\end{array}$ & $\begin{array}{c}\text { Manufacturing } \\
\text { output } \\
\text { (2) }\end{array}$ & $\begin{array}{l}\text { Horse power } \\
\text { per capita } \\
\text { (3) }\end{array}$ & $\begin{array}{c}\text { Proto } \\
\text { industrialization } \\
\text { (4) }\end{array}$ & $\begin{array}{c}\text { GVA per capita } \\
1886 \\
\text { (5) }\end{array}$ & $\begin{array}{c}\text { GVA per capita } \\
1901 \\
\text { (6) }\end{array}$ \\
\hline Gender gap index & $(0.199)$ & $(0.229)$ & $(0.862)$ & $(0.342)$ & $(0.450)$ & $(0.471)$ \\
\hline Control variables & Yes & Yes & Yes & Yes & Yes & Yes \\
\hline
\end{tabular}

Note: OLS regressions. Dependent variable: gross domestic product per capita (column 1); manufacturing output (column 2); horse power per capita (column 3); proto-industrialization (column 4); gross value added per capita in 1886 and 1901 (column 5 and 6, respectively). Variable of interest: overall index (in each specification). Control variables: same controls as the ones used in Table 6. Standardized $\beta$ coefficients. Robust standard errors in parentheses ${ }^{\star} p<0.05,{ }^{\star \star} p<0.01,{ }^{\star \star \star} p<0.001$. 
which could also easily be extended to incorporate dynamic components and be generalizable to other countries.

Based on an original county-level dataset of 86 observations in the mid-nineteenth century stemming from the Statistique Générale de la France, I built an index quantifying the size of the gap between men's and women's achievements in three critical areas: economic participation and opportunities, educational attainment, and health and survival. The county comparisons enabled me to identify the strengths and weaknesses of the French regions in closing the gender gap. The geographical distribution of the index highlighted the existence of a great heterogeneity across regions. In particular, it showed that the counties located on the Northern part of France performed best.

The analysis of the determinants of the gender gap contributes to revealing some specific characteristics of the regions that were performing the best. Counties characterized by greater education for boys and girls, dynamic industries employing high shares of female and male workers, and those offering women access to well-paid jobs displayed higher gender equality. Additional results showed that counties with higher shares of married women displayed lower scores on the various dimensions of gender equality. Further inquiry conducted on family structures showed that the types of nuclear family displayed greater gender equality than the types of extended family.

The third contribution of the paper was to investigate the association between gender equality and economic growth in the past. The analysis showed a positive and significant association between gender equality and economic growth. The results hold regardless of the variable used to measure economic performance. French counties that have succeeded best at closing their gender gap have displayed better economic performance and exhibited lower fertility rates. This association is consistent with the literature stating that empowering women affected fertility in various ways [see Caldwell (1981), and Brée and de la Croix (2019) for an empirical investigation of the French town of Rouen in the seventeenth and eighteenth centuries] and is beneficial to economic growth [see Kabeer and Natali (2013), Cuberes and Teignier (2014), and Klasen and Santos Silva (2018), for exhaustive reviews of the literature], and confirms the theory developed by Diebolt and Perrin (2013, 2019) according to which female empowerment in the direction of greater equality underlies the demographic transition and triggers sustained economic growth.

Additionally, the analysis shows that the overall index-which encompasses the wider variety of gender indicators-and the education sub-index capture many more variations in economic performance than the economic and health sub-indices. Taken together, the analyses of the determinants of gender equality and the effect of gender equality on economic growth have wide political implications. Our results endorse the importance of accounting for the multidimensional aspects of gender equality in economic growth. They suggest that, to be more efficient, policies in favor of economic development must rely on an approach that fosters gender equality on all its many dimensions. Policies must account for the wide range of determinants that affect gender equality, e.g., girls' and boys' education, women's access to resources and opportunities, but also culture and social norms embedded in the territory, as reflected by the family structures, that can profoundly and durably affect individuals' behaviors with regards to gender equality.

To conclude, it is important to acknowledge that the empirical results of this paper are limited to simple correlations. Further analysis is required to determine the direction(s) of 
causation between the various factors that were integrated and discussed in the current analysis. In any case, the current investigation may not capture the full complexity of the relationships of interest and further research on this point is needed. The 1850s gender gap index is a first step toward the generalization of the index to longer time periods-such as would enable us to account for the dynamic evolution of gender equality over time-and toward the extension of the index to other countries from a comparative perspective. The ultimate ambition of this work is to deepen the understanding of economic and demographic processes and maybe bring elements of answers to some of the most persistent puzzles underlying the long-run development process.

Acknowledgements. I am grateful to the anonymous referees for their valuable comments and suggestions. I also thank the participants of the following conferences and seminars for their feedbacks and comments on an earlier version of the paper: Macrohistory Seminar, University of Bonn; XVIIth World Economic History Congress, Kyoto; European Historical Economics Society Conference, Pisa; Workshop on Women in Changing Labor Markets, Lund; 24th IAFFE Annual Conference-Gender Equality in Challenging Times, Berlin; Odense FRESH Meeting; Debunking Austerity: Towards Alternative Economic Policy Scenarios, SSSUP, Pisa. The paper has also benefitted from precious feedbacks from Audrey-Rose Menard.

\section{References}

Bardhan, Kalpana and Stephan Klasen (1999) UNDP's gender-related indices: a critical review. World Development 27(6), 985-1010.

Becker, Sascha O. and L. Woessmann (2009) Was weber wrong? A human capital theory of protestant economic history. Quarterly Journal of Economics 124(2), 531-596.

Bertinelli, Luisito and Duncan Black (2004) Urbanization and growth. Journal of Urban Economics 56(1), $80-96$.

Bertocchi, Graziella and Monica Bozzano (2019) Gender gaps in education. GLO Discussion Paper, No. 415, Global Labor Organization (GLO), Essen.

Blanc, Guillaume (2020) Demographic change and development from crowdsourced genealogies in early modern Europe. Working Paper. Brown University.

Bloom, David E., David Canning and Jaypee Sevilla (2004) The effect of health on economic growth: a production function approach. World Development 32(1), 1-13.

Bloom, David E. and Jeffrey G. Williamson (1998) Demographic transition and economic miracles in emerging Asia. World Bank Economic Review 12(3), 419-455.

Branisa, Boris, Stephan Klasen, Maria Ziegler, Denis Dreschler and Johannes Jütting (2014) The institutional basis of gender inequality: the social institutions and gender index (SIGI). Feminist Economics 20(2), 29-64.

Brée, Sandra and David de la Croix (2019) Key forces behind the decline of fertility-lessons from childlessness in Rouen before the industrial revolution. Cliometrica 13, 25-54.

Carmichael, Sarah (2011) Marriage and power: age at first marriage and spousal age gap in lesser developed countries. The History of the Family 16(4), 416-436.

Caruana-Galizia, Paul (2013) Estimating French regional income: departmental per capita gross value added, 1872-1911. Research in Economic History 29, 71-95.

Combes, Pierre-Philippe, Miren Lafourcade, Jacques-François Thisse and Jean-Claude Toutain (2011) The rise and fall of spatial inequalities in France: a long-run perspective. Explorations in Economic History 48, 243-271.

Cuberes, David and Marc Teignier (2014) Gender inequality and economic growth: a critical review. Journal of International Development 26(2), 260-276.

Cummins, Neil (2009) Why did fertility decline? An analysis of the individual level economics correlates of the nineteenth century fertility transition in England and France. PhD thesis, The London School of Economics and Political Science (LSE). 
De la Croix, David and Marie Van der Donckt (2010) Would empowering women initiate the demographic transition in least developed countries? Journal of Human Capital 4(2), 85-129.

De Pleijt, Alexandra and Jan Luiten van Zanden (2018) Two worlds of female labour: gender wage inequality in Western Europe, 1300-1800. European Historical Economics Society (EHES), Working Papers 0138.

Diebolt, Claude, Audrey-Rose Menard and Faustine Perrin (2017) Behind the fertility-education nexus: what triggered the French development process? European Review of Economic History 21(4), 357-392.

Diebolt, Claude and Faustine Perrin (2013) From stagnation to sustained growth: the role of female empowerment. American Economic Review, Papers \& Proceedings 103(3), 545-549.

Diebolt, Claude, and Faustine Perrin (2019) A cliometric model of unified growth. Gender equality and family organization in the long run of history. In C. Diebolt, S. Carmichael, S. Dilli, A. Rijpma and C. Störmer (eds.), Cliometrics of the Family: Global Patterns and Their Impact on Diverging Development, Studies in Economic History. Editions Springer, pp. 7-31.

Dijkstra, A. Geske and Lucia C. Hanmer (2000) Measuring socio-economic gender inequality: towards an alternative to the UNDP gender-related development index. Feminist Economics 6(2), 41-75.

Dilli, Selin, Sarah G. Carmichael and Auke Rijpma (2019) Introducing the historical gender equality index. Feminist Economics 25(1), 31-57.

Doepke, Matthias (2004) Accounting for fertility decline during the transition to growth. Journal of Economic Growth 9, 347-383.

Doepke, Matthias and Michèle Tertilt (2009) Women's liberation: what's in it for men? The Quarterly Journal of Economics 124(4), 1541-1591.

Dollar, David and Roberta Gatti (1999) Gender inequality, income and growth: are good times good for women? Policy Research Report on Gender and Development Working Paper Series, 1, The World Bank, Washington, DC.

Duflo, Ester (2012) Women empowerment and economic development. Journal of Economic Literature 50 (4), 1051-1079.

Galor, Oded and Omer Moav (2002) Natural selection and the origin of economic growth. Quarterly Journal of Economics 117, 1133-1191.

Galor, Oded, Omer Moav and Dietrich Vollrath (2009) Inequality in landownership, the emergence of human-capital promoting institutions, and the great divergence. The Review of Economic Studies 76 (1), 143-179.

Galor, Oded and David N. Weil (1996) The gender gap, fertility, and growth. American Economic Review 86 (3), 374-387.

Galor, Oded and David N. Weil (1999) From Malthusian stagnation to modern growth. American Economic Review 89, 150-154.

Galor, Oded and David N. Weil (2000) Population, technology, and growth: from Malthusian stagnation to the demographic transition and beyond. American Economic Review 90, 806-828.

Gary, Kathryn (2017) Constructing equality? Women's wages for physical labor 1550-1759. Lund Papers in Economic History 158, Lund University, Department of Economic History.

Goldin, Claudia (1990) Understanding the Gender Gap: An Economic History of American Women. New York: Oxford University Press, 306 p.

Goldin, Claudia (1994) The U-shaped female labor force function in economic development and economic history. National Bureau of Economic Research (Cambridge, MA) Working Paper No. 4707.

Grech, Victor, Charles Savona-Ventura and P. Vassallo-Agius (2002) Unexplained differences in sex ratios at birth in Europe and North America. BMJ 324(7344), 1010-1011.

Harvey, Edward B., John H. Blakely and Lorne Tepperman (1990) Towards an index of gender equality. Social Indicators Research 22, 299-317.

Hausmann, Ricardo, Laura D. Tyson and Saadia Zahidi (2006) The global gender gap report 2006. World Economic Forum.

Humphries, Jane and Jacob Weisdorf (2015) The wages of women in England, 1260-1850. The Journal of Economic History 75(2), 405-447.

Jejeebhoy, Shireen J. (1995) Women's Education, Autonomy and Reproductive Behaviour: Experiences from Developing Countries. Oxford, UK: Clarendon Press.

John, Caldwell (1981) The mechanisms of demographic change in historical perspective. Population Studies 35(1), 5-27. 
Kabeer, Naila and Luisa Natali (2013) Gender equality and economic growth: is there a win-win? IDS Working Papers 417, 1-58.

Klasen, Stephan (2002) Low schooling for girls, slower growth for All? Cross-country evidence on the effect of gender equality in education on economic development. World Bank Economic Review 16, 345-373.

Klasen, Stephan and Francesca Lamanna (2009) The impact of gender inequality in education and employment on economic growth: new evidence for a panel of countries. Feminist Economics 15(3), 97-132.

Klasen, Stephan and Manuel Santos Silva (2018) Gender inequality as a barrier to economic growth: a review of the theoretical literature. Courant Research Centre: Poverty, Equity and Growth-Discussion Papers 252, Courant Research Centre PEG.

Knowles, Stephen, Paula K. Lorgelly and P. Dorian Owen (2002) Are educational gender gaps a brake on economic development? Some cross-country empirical evidence. Oxford Economic Papers 54(1), 118149.

Lagerlöf, Nils-Petter (2003) Gender equality and long-run growth. Journal of Economic Growth 8(4), 403426.

Le Bras, Hervé and Emmanuel Todd (2013) Le Mystère Français. Paris: Seuil, 308 p.

Maubrigades, Silvana (2015) Connections between women`s age at marriage and social and economic development. In M. Camou, S. Maubrigades and R. Thorp (eds.), Gender Inequalities and Development in Latin America during the Twentieth Century. England: Ashgate.

Perrin, Faustine (2013) Gender equality and economic growth in the long-run. A cliometric analysis. PhD Dissertation, University of Strasbourg-Scuola Superiore Sant'Anna, 352 p.

Perrin, Faustine (2014) On the construction of a historical gender gap index. An implementation on French data. AFC Working Paper, WP2014-5, 28 pages.

Perrin, Faustine, and Michael Benaim (2019) Regional patterns of economic development: France during the industrialization. In C. Diebolt, S. Carmichael, S. Dilli, A. Rijpma and C. Störmer (eds.), Cliometrics of the Family: Global Patterns and Their Impact on Diverging Development, Studies in Economic History, pp. 197-235 Switzerland: Springer nature.

Prettner, Klaus and Holger Strulik (2017) Gender equity and the escape from poverty. Oxford Economic Papers 69(1), 55-74.

Schüler, Dana (2006) The uses and misuses of the gender-related development index and gender empowerment measure: a review of the literature. Journal of Human Development 7(2), 161-181.

Schultz, T. Paul (1995) Investments in schooling and health of women and men: quantities and returns. Journal of human resources 694-734.

Sugarman David, B, and Murray A Straus (1988) Indicators of gender equality for American states and regions. Social Indicators Research 20(3), 229-270.

Todd, Emmanuel (1990) L'invention de l'Europe. Paris: Editions du Seuil.

Todd, Emmanuel (2011) L'origine des systèmes familiaux. Tome I, Paris: Gallimard.

Wrigley, Edward A. (1985) The fall of marital fertility in nineteenth-century France: exemplar or exception? (part I). European Journal of Population 1(1), 31-60.

Yllö, Kersti (1984) The status of women, marital equality, and violence against wives. A contextual analysis. Journal of Family Issues 5(3), 307-320. 


\section{Appendix A}

\section{The gender gap index}

The data used to construct the index were mainly extracted from books published by the Statistique Générale de la France (SGF) on population and demographic and public education censuses, between 1800 and 1925. Almost all the data were available for 86 counties.

Table A.1. Structure of the 1850 s gender gap index

\begin{tabular}{|c|c|c|}
\hline Sub-index & Variables & Sources \\
\hline \multirow[t]{4}{*}{$\begin{array}{l}\text { Economic } \\
\text { opportunity }\end{array}$} & $\begin{array}{l}\text { Ratio: female labor force in } \\
\text { agriculture over male value }\end{array}$ & $\begin{array}{l}\text { Statistique Générale de la France, } \\
\text { Recensement } 1851\end{array}$ \\
\hline & $\begin{array}{l}\text { Ratio: female labor force in } \\
\text { industry over male value }\end{array}$ & $\begin{array}{l}\text { Statistique Générale de la France, } \\
\text { Recensement } 1851\end{array}$ \\
\hline & $\begin{array}{l}\text { Ratio: female wage over male } \\
\text { value in manufacturing }\end{array}$ & $\begin{array}{l}\text { Statistique Générale de la France, } \\
\text { Statistique industriel, } 1861\end{array}$ \\
\hline & $\begin{array}{l}\text { Ratio: female wage over male } \\
\text { value in agriculture }\end{array}$ & $\begin{array}{l}\text { Statistique Générale de la France, } \\
\text { Enquête agricole, } 1852\end{array}$ \\
\hline \multirow[t]{3}{*}{$\begin{array}{l}\text { Educational } \\
\text { attainment }\end{array}$} & $\begin{array}{l}\text { Ratio: female literacy rate over } \\
\text { male value }\end{array}$ & $\begin{array}{c}\text { Statistique Générale de la France, } \\
\text { Enseignement primaire, } 1854\end{array}$ \\
\hline & $\begin{array}{l}\text { Ratio: female enrollment rate in } \\
\text { primary school over male } \\
\text { value }\end{array}$ & $\begin{array}{l}\text { Statistique Générale de la France, } \\
\text { Enseignement primaire, } 1850\end{array}$ \\
\hline & $\begin{array}{l}\text { Ratio: female public primary } \\
\text { schools over male value }\end{array}$ & $\begin{array}{l}\text { Statistique Générale de la France, } \\
\text { Enseignement Primaire, } 1850\end{array}$ \\
\hline \multirow[t]{3}{*}{$\begin{array}{c}\text { Health and } \\
\text { survival }\end{array}$} & $\begin{array}{l}\text { Ratio: female live births over } \\
\text { male value }\end{array}$ & $\begin{array}{l}\text { Statistique Générale de la France, } \\
\text { Recensement, } 1851\end{array}$ \\
\hline & $\begin{array}{l}\text { Ratio: female mortality over } \\
\text { male value }\end{array}$ & $\begin{array}{l}\text { Statistique Générale de la France, } \\
\text { Recensement, } 1851\end{array}$ \\
\hline & $\begin{array}{l}\text { Ratio: female life expectancy } \\
\text { over male value }\end{array}$ & $\begin{array}{l}\text { Statistique Générale de la France, } \\
\text { Recensement-Mouvement de la } \\
\text { population, } 1856\end{array}$ \\
\hline
\end{tabular}

\section{Variables}

- Female (Male) in industry, in 1851. Number of women (men) employed in manufacturing over total number of women (men) aged 15-60. Manufacturing refers to all types of industry: textiles, the metals sector, and other factories (food, wood, construction, etc.).

- Female (Male) in agriculture, in 1851. Number of women (men) employed in agriculture over total number of women (men) aged 15-60. Agriculture refers to all positions within the agricultural sector: owners, farmers, sharecroppers, and others.

- Female (Male) wages in industry, in 1861. Average of female (male) workers' wages in francs in different industries proportionally to the weight of females (males) in 


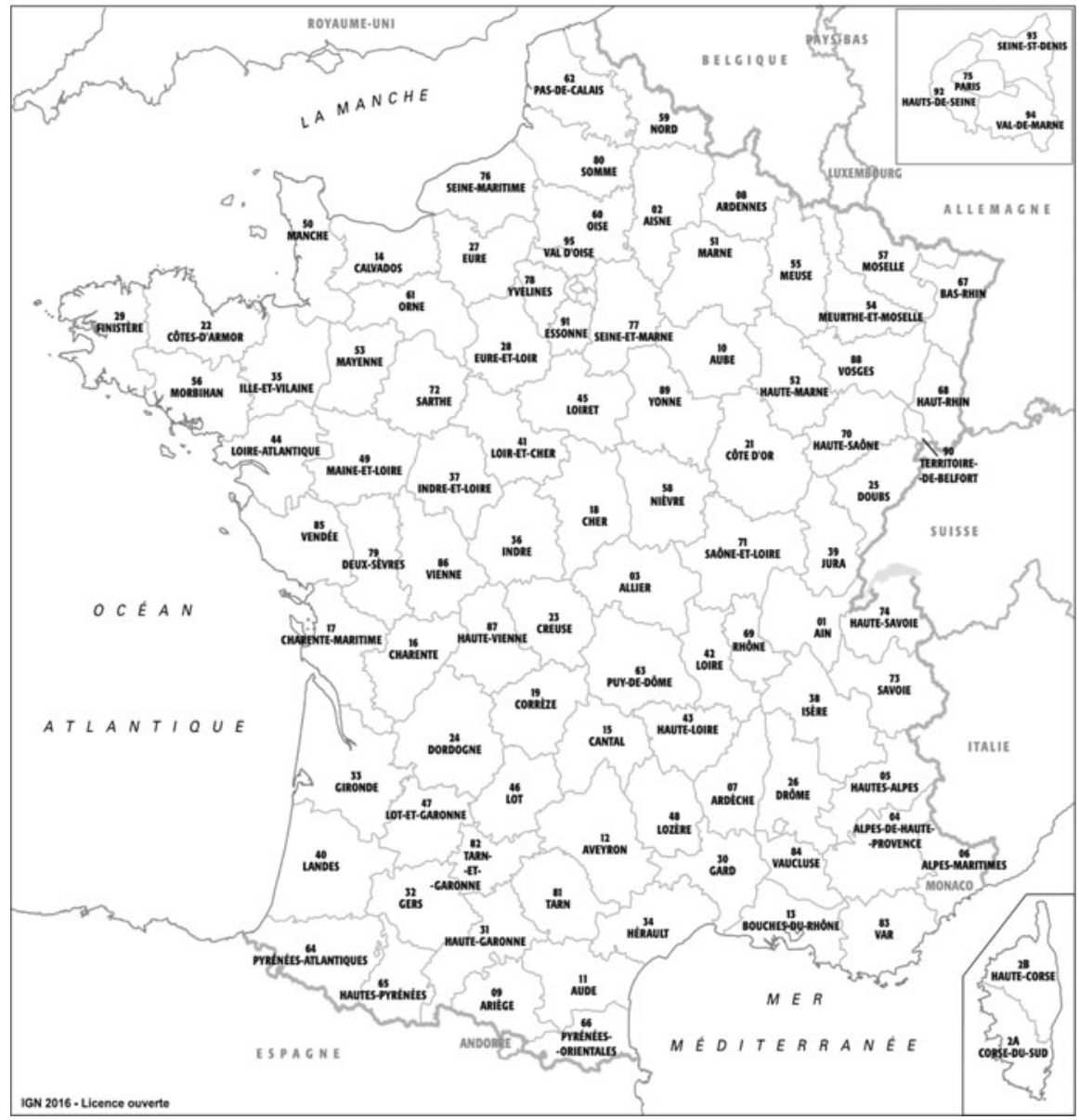

Figure A.1. Administrative France.

Source: https://www.ign.fr/institut/ressources-pedagogiques\#Fonds2

Note: The names of several départements have changed over time. Before 1970, the Alpes-de-Haute-Provence was called Basses-Alpes; before 1941, the Charente-Maritime was known as the Charente-Inférieure; before 1955, the Seine-Maritime was entitled Seine-Inférieure; and before 1968, Paris, Hauts-de-Seine, Seine-Saint-Denis, and Val-de-Marne composed the Seine, while Yvelines, Essonne, and Val-d'Oise together were known as the Seine-et-Oise.

each industry for each department. Manufacturing refers to all types of industry: textiles, the metal sector, and other factories (food, wood, construction, etc.)

- Female (Male) wages in agriculture, in 1852. Average of female (male) farm workers' wages in francs for one working day in the agricultural sector.

- Female (Male) literacy rate, in 1854. The literacy rate consists of the number of individuals able to read and to write over total population. 1856-66

- Girls' (Boys') enrollment rate, in 1850. Number of girls (boys) enrolled in public primary schools over the total number of girls (boys) aged 5-15.

- Girls' (Boys') public primary schools, in 1850. Number of public primary schools dedicated to girls (boys). 
- Life expectancy at age $\mathbf{0}$, in 1856. The life expectancy is the expected (in the statistical sense) number of years of life remaining at a given age (here at age 0) calculated by constructing a life table.

- Female (Male) live births in 1851. Number of female (male) living births.

- Female (Male) mortality rate in 1851. Number of women (men) who died per 1,000 living women (men).

\section{Appendix B}

\section{Empirical analysis}

The data used to conduct the empirical analysis were mainly extracted from books published by the Statistique Générale de la France (SGF) on population, demographic, industrial, agricultural, and educational censuses, between 1800 and 1925. Almost all data were available for 86 counties.

\section{Variables}

- Density. Number of individuals per $\mathrm{km}^{2}, 1851$.

- Urban residents. Number of individuals living in towns with more than 2,000 inhabitants in total, 1851.

- Share married women. Number of married women per women of marriageable age (15+), 1851.

- Individuals per house. Number of individuals living per house, 1852.

- Child-women ratio. Number of children aged 0-5 per woman of childbearing age (15-45), 1851

- Infant mortality. Mortality rate at age 0 (from life table), 1851.

- Female age at marriage. Women's mean age at marriage, 1855.

- Landownership inequality. Number of monetary contributions above 300 francs over land ownership per total number of monetary contributions over land ownership, 1835.

- Gross value added per capita, in 1860, 1886, 1901. From Caruana-Galizia (2013).

- GDP per capita. Value added in agriculture, industry, a tertiary sector per capita (in thousands), 1860. From Combes et al. (2011)

- Manufacture output. Manufacturing output per capita, 1861

- Horse power per capita. Horse power of steam engines per capita (in 10,000), 1861.

- Proto-industrialization. Number of steam engines per capita (in thousands), 1861.

- Family structure. Stem family (famille souche+famille souche imparfaite); Intermediary/Communitarian family (famille communautaire + zone atlantique intermédiaire +famille nucléaire à corésidence $d u$ nord +formes nucléaires imparfaites et communautaires bretonnes); Cooperative (famille nucláire patrilocale égalitaire); Nuclear absolute family (famille hypernucléaire de l'Ouest); Nuclear egalitarian family (famille nucléaire égalitaire). See Le Bras and Todd (2013). 
Table A.2. Ranking and scores: overall index

\begin{tabular}{|c|c|c|c|c|c|}
\hline County & $\begin{array}{l}\text { Overall } \\
\text { ranking }\end{array}$ & $\begin{array}{l}\text { Overall } \\
\text { score }\end{array}$ & $\begin{array}{l}\text { Economic } \\
\text { ranking }\end{array}$ & $\begin{array}{l}\text { Educational } \\
\text { ranking }\end{array}$ & $\begin{array}{l}\text { Health } \\
\text { ranking }\end{array}$ \\
\hline Mayenne & 1 & 0.8629 & 9 & 1 & 53 \\
\hline Manche & 2 & 0.8403 & 46 & 2 & 12 \\
\hline Vosges & 3 & 0.8298 & 6 & 10 & 1 \\
\hline Seine-Inférieure & 4 & 0.8221 & 5 & 11 & 3 \\
\hline Haut-Rhin & 5 & 0.8193 & 3 & 9 & 22 \\
\hline Sarthe & 6 & 0.8159 & 11 & 5 & 27 \\
\hline Seine & 7 & 0.8082 & 60 & 3 & 57 \\
\hline Ille-Et-Vilaine & 8 & 0.8062 & 16 & 6 & 39 \\
\hline Meuse & 9 & 0.8013 & 27 & 7 & 23 \\
\hline Orne & 10 & 0.7949 & 8 & 16 & 18 \\
\hline Haute-Saône & 11 & 0.7920 & 24 & 13 & 25 \\
\hline Maine-Et-Loire & 12 & 0.7889 & 49 & 4 & 66 \\
\hline Doubs & 13 & 0.7879 & 19 & 12 & 65 \\
\hline Bas-Rhin & 14 & 0.7863 & 4 & 17 & 71 \\
\hline Moselle & 15 & 0.7808 & 14 & 18 & 38 \\
\hline Meurthe $^{a}$ & 16 & 0.7783 & 76 & 8 & 10 \\
\hline Rhône & 17 & 0.7782 & 2 & 22 & 61 \\
\hline Eure & 18 & 0.7772 & 13 & 21 & 34 \\
\hline Calvados & 19 & 0.7725 & 40 & 15 & 28 \\
\hline Marne & 20 & 0.7677 & 12 & 26 & 26 \\
\hline Jura & 21 & 0.7633 & 22 & 20 & 75 \\
\hline Loire & 22 & 0.7582 & 57 & 19 & 24 \\
\hline Isère & 23 & 0.7497 & 25 & 35 & 20 \\
\hline Aube & 24 & 0.7448 & 20 & 29 & 67 \\
\hline Haute-Marne & 25 & 0.7445 & 81 & 14 & 49 \\
\hline Loiret & 26 & 0.7433 & 48 & 30 & 7 \\
\hline Nord & 27 & 0.7425 & 38 & 27 & 51 \\
\hline Seine-Et-Oise & 28 & 0.7410 & 64 & 23 & 36 \\
\hline Côte-D’Or & 29 & 0.7397 & 53 & 25 & 46 \\
\hline Somme & 30 & 0.7379 & 42 & 31 & 37 \\
\hline Aisne & 31 & 0.7362 & 54 & 32 & 19 \\
\hline Yonne & 32 & 0.7339 & 63 & 33 & 11 \\
\hline Morbihan & 33 & 0.7323 & 39 & 39 & 2 \\
\hline
\end{tabular}


Table A.2. (Continued.)

\begin{tabular}{|c|c|c|c|c|c|}
\hline County & $\begin{array}{l}\text { Overall } \\
\text { ranking }\end{array}$ & $\begin{array}{l}\text { Overall } \\
\text { score }\end{array}$ & $\begin{array}{l}\text { Economic } \\
\text { ranking }\end{array}$ & $\begin{array}{c}\text { Educational } \\
\text { ranking }\end{array}$ & $\begin{array}{l}\text { Health } \\
\text { ranking }\end{array}$ \\
\hline Oise & 34 & 0.7319 & 41 & 34 & 43 \\
\hline Pas-De-Calais & 35 & 0.7307 & 17 & 40 & 42 \\
\hline Ardennes & 36 & 0.7297 & 58 & 24 & 70 \\
\hline Drôme & 37 & 0.7268 & 1 & 41 & 83 \\
\hline Eure-Et-Loir & 38 & 0.7242 & 52 & 36 & 30 \\
\hline Seine-Et-Marne & 39 & 0.7235 & 68 & 28 & 56 \\
\hline Côtes-Du-Nord & 40 & 0.7184 & 34 & 44 & 5 \\
\hline Hautes-Alpes & 41 & 0.7180 & 23 & 38 & 81 \\
\hline Saône-Et-Loire & 42 & 0.7164 & 21 & 46 & 40 \\
\hline Allier & 43 & 0.7150 & 50 & 37 & 55 \\
\hline Loire-Inférieure & 44 & 0.7131 & 37 & 47 & 6 \\
\hline Ain & 45 & 0.7030 & 10 & 52 & 76 \\
\hline Loir-Et-Cher & 46 & 0.7015 & 70 & 43 & 15 \\
\hline Cantal & 47 & 0.6923 & 30 & 56 & 41 \\
\hline Vendée & 48 & 0.6915 & 59 & 48 & 44 \\
\hline Gard & 49 & 0.6902 & 65 & 49 & 31 \\
\hline Indre-Et-Loire & 50 & 0.6858 & 74 & 42 & 72 \\
\hline Landes & 51 & 0.6784 & 7 & 71 & 9 \\
\hline Tarn & 52 & 0.6781 & 71 & 51 & 63 \\
\hline Lozère & 53 & 0.6773 & 36 & 53 & 84 \\
\hline Vaucluse & 54 & 0.6770 & 33 & 60 & 58 \\
\hline Nièvre & 55 & 0.6767 & 73 & 55 & 17 \\
\hline Finistère & 56 & 0.6759 & 15 & 64 & 47 \\
\hline Corrèze & 57 & 0.6702 & 32 & 65 & 29 \\
\hline Hérault & 58 & 0.6694 & 44 & 58 & 77 \\
\hline Indre & 59 & 0.6684 & 55 & 45 & 86 \\
\hline Tarn-Et-Garonne & 60 & 0.6677 & 31 & 63 & 62 \\
\hline Charente-Inférieure & 61 & 0.6670 & 72 & 62 & 4 \\
\hline Basses-Alpes & 62 & 0.6669 & 62 & 57 & 69 \\
\hline Cher & 63 & 0.6596 & 84 & 54 & 21 \\
\hline Ardèche & 64 & 0.6588 & 28 & 70 & 45 \\
\hline Vienne & 65 & 0.6580 & 66 & 59 & 68 \\
\hline Lot-Et-Garonne & 66 & 0.6507 & 69 & 67 & 13 \\
\hline
\end{tabular}


Table A.2. (Continued.)

\begin{tabular}{|c|c|c|c|c|c|}
\hline County & $\begin{array}{l}\text { Overall } \\
\text { ranking }\end{array}$ & $\begin{array}{l}\text { Overall } \\
\text { score }\end{array}$ & $\begin{array}{c}\text { Economic } \\
\text { ranking }\end{array}$ & $\begin{array}{l}\text { Educational } \\
\text { ranking }\end{array}$ & $\begin{array}{l}\text { Health } \\
\text { ranking }\end{array}$ \\
\hline Haute-Garonne & 67 & 0.6415 & 78 & 69 & 16 \\
\hline Gironde & 68 & 0.6395 & 80 & 61 & 78 \\
\hline Haute-Vienne & 69 & 0.6338 & 51 & 72 & 59 \\
\hline Aveyron & 70 & 0.6318 & 47 & 74 & 54 \\
\hline Hautes-Pyrénées & 71 & 0.6307 & 35 & 79 & 14 \\
\hline Bouches-Du-Rhône & 72 & 0.6298 & 86 & 50 & 74 \\
\hline Creuse & 73 & 0.6245 & 18 & 80 & 73 \\
\hline Var & 74 & 0.6234 & 82 & 66 & 48 \\
\hline Charente & 75 & 0.6212 & 43 & 73 & 82 \\
\hline Dordogne & 76 & 0.6173 & 56 & 76 & 64 \\
\hline Puy-De-Dôme & 77 & 0.6167 & 67 & 75 & 52 \\
\hline Deux-Sèvres & 78 & 0.6148 & 79 & 68 & 85 \\
\hline Lot & 79 & 0.6090 & 29 & 85 & 50 \\
\hline Haute-Loire & 80 & 0.6088 & 45 & 83 & 32 \\
\hline Basses-Pyrénées & 81 & 0.6082 & 75 & 78 & 35 \\
\hline Gers & 82 & 0.6058 & 26 & 82 & 80 \\
\hline Ariège & 83 & 0.5943 & 83 & 81 & 8 \\
\hline Aude & 84 & 0.5940 & 85 & 77 & 33 \\
\hline Corse $^{a}$ & 85 & 0.5797 & 61 & 86 & 60 \\
\hline Pyrénées-Orientales & 86 & 0.5765 & 77 & 84 & 79 \\
\hline
\end{tabular}

${ }^{\mathrm{a}}$ These counties had missing data for 1 out of 10 variables. 

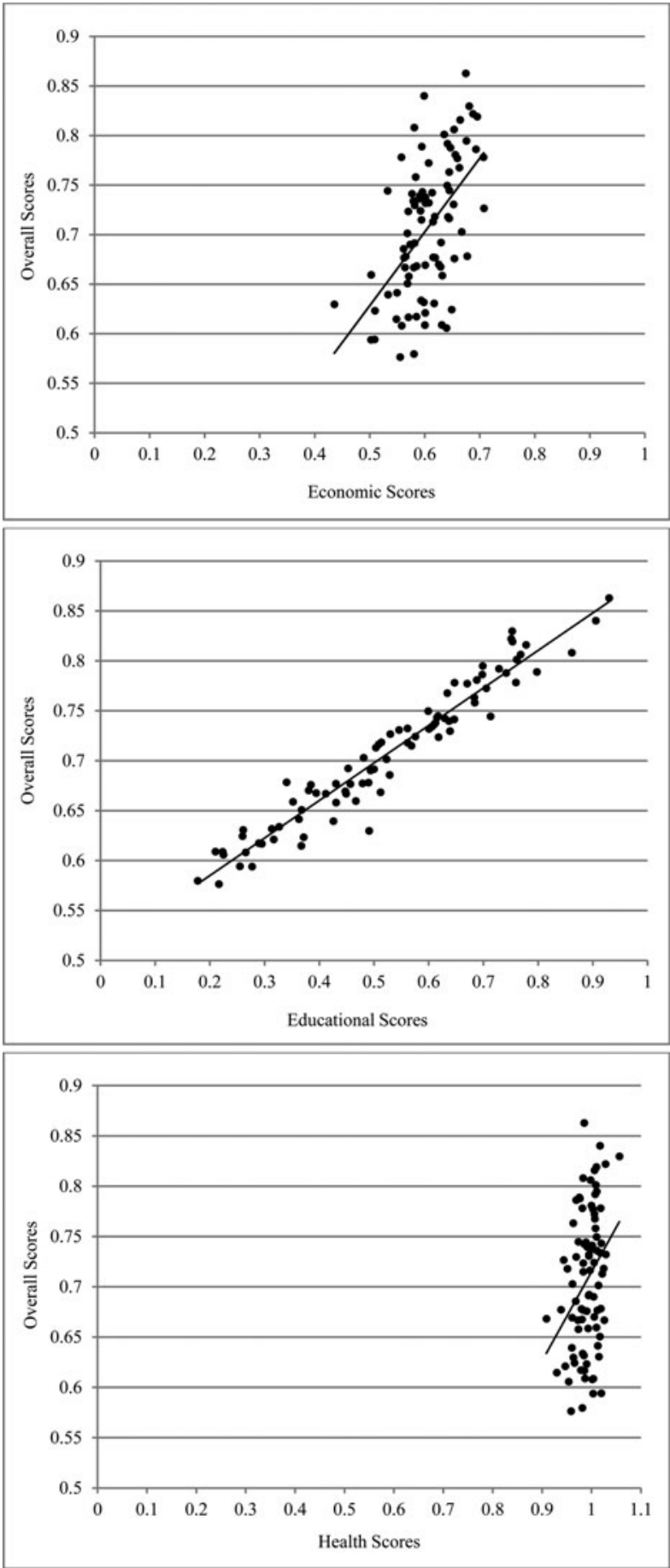

Figure A.2. Sub-index scores in relation to gender gap index scores. 
$412 \quad$ Faustine Perrin

Table A.3. Ranking by sub-index-economic opportunity and participation

\begin{tabular}{|c|c|c|c|c|c|}
\hline County & Score & Rank & County & Score & Rank \\
\hline Drôme & 0.7073 & 1 & Hérault & 0.6004 & 44 \\
\hline Rhône & 0.7065 & 2 & Haute-Loire & 0.5999 & 45 \\
\hline Haut-Rhin & 0.6951 & 3 & Manche & 0.5985 & 46 \\
\hline Bas-Rhin & 0.6927 & 4 & Aveyron & 0.5981 & 47 \\
\hline Seine-Inférieure & 0.6874 & 5 & Loiret & 0.5955 & 48 \\
\hline Vosges & 0.6806 & 6 & Maine-Et-Loire & 0.5943 & 49 \\
\hline Landes & 0.6769 & 7 & Allier & 0.5938 & 50 \\
\hline Orne & 0.6756 & 8 & Haute-Vienne & 0.5932 & 51 \\
\hline Mayenne & 0.6742 & 9 & Eure-Et-Loir & 0.5920 & 52 \\
\hline Ain & 0.6669 & 10 & Côte-D'Or & 0.5911 & 53 \\
\hline Sarthe & 0.6639 & 11 & Aisne & 0.5889 & 54 \\
\hline Marne & 0.6625 & 12 & Indre & 0.5850 & 55 \\
\hline Eure & 0.6590 & 13 & Dordogne & 0.5846 & 56 \\
\hline Moselle & 0.6551 & 14 & Loire & 0.5831 & 57 \\
\hline Finistère & 0.6534 & 15 & Ardennes & 0.5815 & 58 \\
\hline Ille-Et-Vilaine & 0.6530 & 16 & Vendée & 0.5812 & 59 \\
\hline Pas-De-Calais & 0.652 & 17 & Seine & 0.5805 & 60 \\
\hline Creuse & 0.6486 & 18 & Corse* & 0.5801 & 61 \\
\hline Doubs & 0.6463 & 19 & Basses-Alpes & 0.5799 & 62 \\
\hline Aube & 0.6444 & 20 & Yonne & 0.5790 & 63 \\
\hline Saône-Et-Loire & 0.6442 & 21 & Seine-Et-Oise & 0.5766 & 64 \\
\hline Jura & 0.6442 & 22 & Gard & 0.5733 & 65 \\
\hline Hautes-Alpes & 0.6419 & 23 & Vienne & 0.5706 & 66 \\
\hline Haute-Saône & 0.6409 & 24 & Puy-De-Dôme & 0.5701 & 67 \\
\hline Isère & 0.6404 & 25 & Seine-Et-Marne & 0.5670 & 68 \\
\hline Gers & 0.6393 & 26 & Lot-Et-Garonne & 0.5683 & 69 \\
\hline Meuse & 0.6349 & 27 & Loir-Et-Cher & 0.5681 & 70 \\
\hline Ardèche & 0.6316 & 28 & Tarn & 0.5650 & 71 \\
\hline Lot & 0.6307 & 29 & Charente-Inférieure & 0.5638 & 72 \\
\hline Cantal & 0.6294 & 30 & Nièvre & 0.5621 & 73 \\
\hline Tarn-Et-Garonne & 0.6285 & 31 & Indre-Et-Loire & 0.5611 & 74 \\
\hline Corrèze & 0.6251 & 32 & Basses-Pyrénées & 0.5578 & 75 \\
\hline Vaucluse & 0.6185 & 33 & Meurthe & 0.5573 & 76 \\
\hline Côtes-Du-Nord & 0.6179 & 34 & Pyrénées-Orientales & 0.5550 & 77 \\
\hline
\end{tabular}


Table A.3. (Continued.)

\begin{tabular}{llllll}
\hline County & Score & Rank & County & Score & Rank \\
\hline Hautes-Pyrénées & 0.6168 & 35 & Haute-Garonne & 0.5493 & 78 \\
\hline Lozère & 0.6151 & 36 & Deux-Sèvres & 0.5480 & 79 \\
\hline Loire-Inférieure & 0.6148 & 37 & Gironde & 0.5331 & 80 \\
\hline Nord & 0.6131 & 38 & Haute-Marne & 0.5323 & 81 \\
\hline Morbihan & 0.6072 & 39 & Var & 0.5090 & 82 \\
\hline Calvados & 0.6068 & 40 & Ariège & 0.5086 & 83 \\
\hline Oise & 0.6010 & 41 & Cher & 0.5024 & 84 \\
\hline Somme & 0.6008 & 42 & Aude & 0.5020 & 85 \\
\hline Charente & 0.6005 & 43 & Bouches-Du-Rhône & 0.4354 & 86 \\
\hline
\end{tabular}

Table A.4. Ranking by sub-index: educational attainment

\begin{tabular}{|c|c|c|c|c|c|}
\hline County & Score & Rank & County & Score & Rank \\
\hline Mayenne & 0.9295 & 1 & Côtes-Du-Nord & 0.5130 & 44 \\
\hline Manche & 0.9051 & 2 & Indre & 0.5116 & 45 \\
\hline Seine & 0.8612 & 3 & Saône-Et-Loire & 0.5084 & 46 \\
\hline Maine-Et-Loire & 0.7974 & 4 & Loire-Inférieure & 0.5031 & 47 \\
\hline Sarthe & 0.7779 & 5 & Vendée & 0.4996 & 48 \\
\hline Ille-Et-Vilaine & 0.7676 & 6 & Gard & 0.4934 & 49 \\
\hline Meuse & 0.7605 & 7 & Bouches-Du-Rhône & 0.4908 & 50 \\
\hline Meurthe & 0.7591 & 8 & Tarn & 0.4898 & 51 \\
\hline Haut-Rhin & 0.7528 & 9 & Ain & 0.4808 & 52 \\
\hline Vosges & 0.7524 & 10 & Lozère & 0.4788 & 53 \\
\hline Seine-Inférieure & 0.7506 & 11 & Cher & 0.4666 & 54 \\
\hline Doubs & 0.7415 & 12 & Nièvre & 0.4564 & 55 \\
\hline Haute-Saône & 0.7281 & 13 & Cantal & 0.4525 & 56 \\
\hline Haute-Marne & 0.7127 & 14 & Basses-Alpes & 0.4486 & 57 \\
\hline Calvados & 0.7049 & 15 & Hérault & 0.4472 & 58 \\
\hline Orne & 0.6985 & 16 & Vienne & 0.4302 & 59 \\
\hline Bas-Rhin & 0.6975 & 17 & Vaucluse & 0.4301 & 60 \\
\hline Moselle & 0.6877 & 18 & Gironde & 0.4254 & 61 \\
\hline Loire & 0.6837 & 19 & Charente-Inférieure & 0.4115 & 62 \\
\hline Jura & 0.6829 & 20 & Tarn-Et-Garonne & 0.3939 & 63 \\
\hline
\end{tabular}


Table A.4. (Continued.)

\begin{tabular}{|c|c|c|c|c|c|}
\hline County & Score & Rank & County & Score & Rank \\
\hline Eure & 0.6700 & 21 & Finistère & 0.3842 & 64 \\
\hline Rhône & 0.6470 & 22 & Corrèze & 0.3804 & 65 \\
\hline Seine-Et-Oise & 0.6464 & 23 & Var & 0.3712 & 66 \\
\hline Ardennes & 0.6387 & 24 & Lot-Et-Garonne & 0.3673 & 67 \\
\hline Côte-D’Or & 0.6369 & 25 & Deux-Sèvres & 0.3669 & 68 \\
\hline Marne & 0.6339 & 26 & Haute-Garonne & 0.3627 & 69 \\
\hline Nord & 0.6290 & 27 & Ardèche & 0.3516 & 70 \\
\hline Seine-Et-Marne & 0.6176 & 28 & Landes & 0.3398 & 71 \\
\hline Aube & 0.6168 & 29 & Haute-Vienne & 0.3264 & 72 \\
\hline Loiret & 0.6148 & 30 & Charente & 0.3164 & 73 \\
\hline Somme & 0.6119 & 31 & Aveyron & 0.3131 & 74 \\
\hline Aisne & 0.6092 & 32 & Puy-De-Dôme & 0.2947 & 75 \\
\hline Yonne & 0.6051 & 33 & Dordogne & 0.2892 & 76 \\
\hline Oise & 0.6004 & 34 & Aude & 0.2768 & 77 \\
\hline Isère & 0.5987 & 35 & Basses-Pyrénées & 0.2651 & 78 \\
\hline Eure-Et-Loir & 0.5754 & 36 & Hautes-Pyrénées & 0.2605 & 79 \\
\hline Allier & 0.5682 & 37 & Creuse & 0.2595 & 80 \\
\hline Hautes-Alpes & 0.5613 & 38 & Ariège & 0.2547 & 81 \\
\hline Morbihan & 0.5610 & 39 & Gers & 0.2245 & 82 \\
\hline Pas-De-Calais & 0.5456 & 40 & Haute-Loire & 0.2230 & 83 \\
\hline Drôme & 0.5294 & 41 & Pyrénées-Orientales & 0.2162 & 84 \\
\hline Indre-Et-Loire & 0.5283 & 42 & Lot & 0.2099 & 85 \\
\hline Loir-Et-Cher & 0.5225 & 43 & Corse & 0.1777 & 86 \\
\hline
\end{tabular}

Table A.5. Ranking by sub-index: health and survival

\begin{tabular}{lcclcc}
\hline County & Score & Rank & County & Score & Rank \\
\hline Vosges & 1.0565 & 1 & Vendée & 0.9938 & 44 \\
\hline Morbihan & 1.0287 & 2 & Ardèche & 0.9931 & 45 \\
\hline Seine-Inférieure & 1.0282 & 3 & Côte-D’Or & 0.9911 & 46 \\
\hline Charente-Inférieure & 1.0256 & 4 & Finistère & 0.9901 & 47 \\
\hline Côtes-Du-Nord & 1.0242 & 5 & Var & 0.9898 & 48 \\
\hline Loire-Inférieure & 1.0215 & 6 & Haute-Marne & 0.9884 & 49 \\
\hline
\end{tabular}


Table A.5. (Continued.)

\begin{tabular}{|c|c|c|c|c|c|}
\hline County & Score & Rank & County & Score & Rank \\
\hline Loiret & 1.0196 & 7 & Lot & 0.9864 & 50 \\
\hline Ariège & 1.0196 & 8 & Nord & 0.9855 & 51 \\
\hline Landes & 1.0185 & 9 & Puy-De-Dôme & 0.9854 & 52 \\
\hline Meurthe* & 1.0184 & 10 & Mayenne & 0.9851 & 53 \\
\hline Yonne & 1.0176 & 11 & Aveyron & 0.9842 & 54 \\
\hline Manche & 1.0172 & 12 & Allier & 0.9831 & 55 \\
\hline Lot-Et-Garonne & 1.0166 & 13 & Seine-Et-Marne & 0.9831 & 56 \\
\hline Hautes-Pyrénées & 1.0148 & 14 & Seine & 0.9828 & 57 \\
\hline Loir-Et-Cher & 1.0139 & 15 & Vaucluse & 0.9824 & 58 \\
\hline Haute-Garonne & 1.0125 & 16 & Haute-Vienne & 0.9817 & 59 \\
\hline Nièvre & 1.0116 & 17 & Corse & 0.9812 & 60 \\
\hline Orne & 1.0105 & 18 & Rhône & 0.9811 & 61 \\
\hline Aisne & 1.0104 & 19 & Tarn-Et-Garonne & 0.9806 & 62 \\
\hline Isère & 1.0100 & 20 & Tarn & 0.9794 & 63 \\
\hline Cher & 1.0098 & 21 & Dordogne & 0.9783 & 64 \\
\hline Haut-Rhin & 1.0098 & 22 & Doubs & 0.9760 & 65 \\
\hline Meuse & 1.0086 & 23 & Maine-Et-Loire & 0.9751 & 66 \\
\hline Loire & 1.0077 & 24 & Aube & 0.9732 & 67 \\
\hline Haute-Saône & 1.0071 & 25 & Vienne & 0.9731 & 68 \\
\hline Marne & 1.0066 & 26 & Basses-Alpes & 0.9722 & 69 \\
\hline Sarthe & 1.0060 & 27 & Ardennes & 0.9689 & 70 \\
\hline Calvados & 1.0056 & 28 & Bas-Rhin & 0.9688 & 71 \\
\hline Corrèze & 1.0052 & 29 & Indre-Et-Loire & 0.9678 & 72 \\
\hline Eure-Et-Loir & 1.0051 & 30 & Creuse & 0.9653 & 73 \\
\hline Gard & 1.0040 & 31 & Bouches-Du-Rhône & 0.9632 & 74 \\
\hline Haute-Loire & 1.0035 & 32 & Jura & 0.9629 & 75 \\
\hline Aude & 1.0031 & 33 & Ain & 0.9612 & 76 \\
\hline Eure & 1.0028 & 34 & Hérault & 0.9605 & 77 \\
\hline Basses-Pyrénées & 1.0015 & 35 & Gironde & 0.9600 & 78 \\
\hline Seine-Et-Oise & 1.0011 & 36 & Pyrénées-Orientales & 0.9583 & 79 \\
\hline Somme & 1.0009 & 37 & Gers & 0.9537 & 80 \\
\hline Moselle & 0.9996 & 38 & Hautes-Alpes & 0.9509 & 81 \\
\hline Ille-Et-Vilaine & 0.9981 & 39 & Charente & 0.9468 & 82 \\
\hline Saône-Et-Loire & 0.9966 & 40 & Drôme & 0.9436 & 83 \\
\hline
\end{tabular}


Table A.5. (Continued.)

\begin{tabular}{llllll}
\hline County & Score & Rank & County & Score & Rank \\
\hline Cantal & 0.9948 & 41 & Lozère & 0.9379 & 84 \\
\hline Pas-De-Calais & 0.9945 & 42 & Deux-Sèvres & 0.9294 & 85 \\
\hline Oise & 0.9944 & 43 & Indre & 0.9085 & 86 \\
\hline
\end{tabular}

Table B.1. Summary statistics of the variables

\begin{tabular}{|c|c|c|c|c|c|}
\hline Variables & Obs. & Mean & Standard deviation & Min. & Max. \\
\hline \multicolumn{6}{|l|}{ Economic variables } \\
\hline GGI-overall & 87 & 0.7082 & 0.0701 & 0.5765 & 0.8629 \\
\hline GGI-economic & 87 & 0.6064 & 0.0513 & 0.4354 & 0.7073 \\
\hline GGI-education & 87 & 0.5269 & 0.1793 & 0.1777 & 0.9295 \\
\hline GGI-health & 87 & 0.9912 & 0.0249 & 0.9085 & 1 \\
\hline \multicolumn{6}{|l|}{ Family structure } \\
\hline Nuclear egalitarian & 90 & 0.3222 & 0.4699 & 0 & 1 \\
\hline Nuclear absolute & 90 & 0.0778 & 0.2693 & 0 & 1 \\
\hline Intermediate family & 90 & 0.2111 & 0.4104 & 0 & 1 \\
\hline Stem family & 90 & 0.3000 & 0.4608 & 0 & 1 \\
\hline Cooperative & 90 & 0.0889 & 0.2862 & 0 & 1 \\
\hline \multicolumn{6}{|l|}{ Socio-demographic variables } \\
\hline Density & 86 & 1.0118 & 3.1665 & 0.2187 & 29.91 \\
\hline Urban residents & 86 & 0.3241 & 0.1563 & 0.1299 & 0.9081 \\
\hline Share married women & 86 & 0.5346 & 0.0576 & 0.4306 & 0.6415 \\
\hline Individuals per house & 89 & 5.0012 & 2.2071 & 3.35 & 23.96 \\
\hline Child-women ratio & 86 & 0.4771 & 0.0768 & 0.2611 & 0.6929 \\
\hline Infant mortality & 86 & 0.3006 & 0.0781 & 0.1621 & 0.4834 \\
\hline Female age at marriage & 86 & 26.08 & 1.3819 & 23.16 & 29.40 \\
\hline Landownership inequality & 86 & 0.3634 & 0.1788 & 0.0407 & 0.8146 \\
\hline \multicolumn{6}{|l|}{ Economic performance } \\
\hline GVA per capita & 87 & 0.4803 & 0.1391 & 0.2625 & 1.0625 \\
\hline GDP per capita & 89 & 0.4975 & 0.1427 & 0.2730 & 1.1050 \\
\hline Manufacture output & 89 & 0.1715 & 0.1273 & 0.0144 & 0.5772 \\
\hline Horse power per capita & 89 & 0.4087 & 0.9724 & 0 & 8.2123 \\
\hline Proto-industrialization & 86 & 0.2220 & 0.2454 & 0 & 1.2099 \\
\hline GVA per capita 1886 & 85 & 0.7518 & 0.2435 & 0.2669 & 1.3830 \\
\hline GVA per capita 1901 & 85 & 0.8629 & 0.2710 & 0.2553 & 1.8164 \\
\hline
\end{tabular}




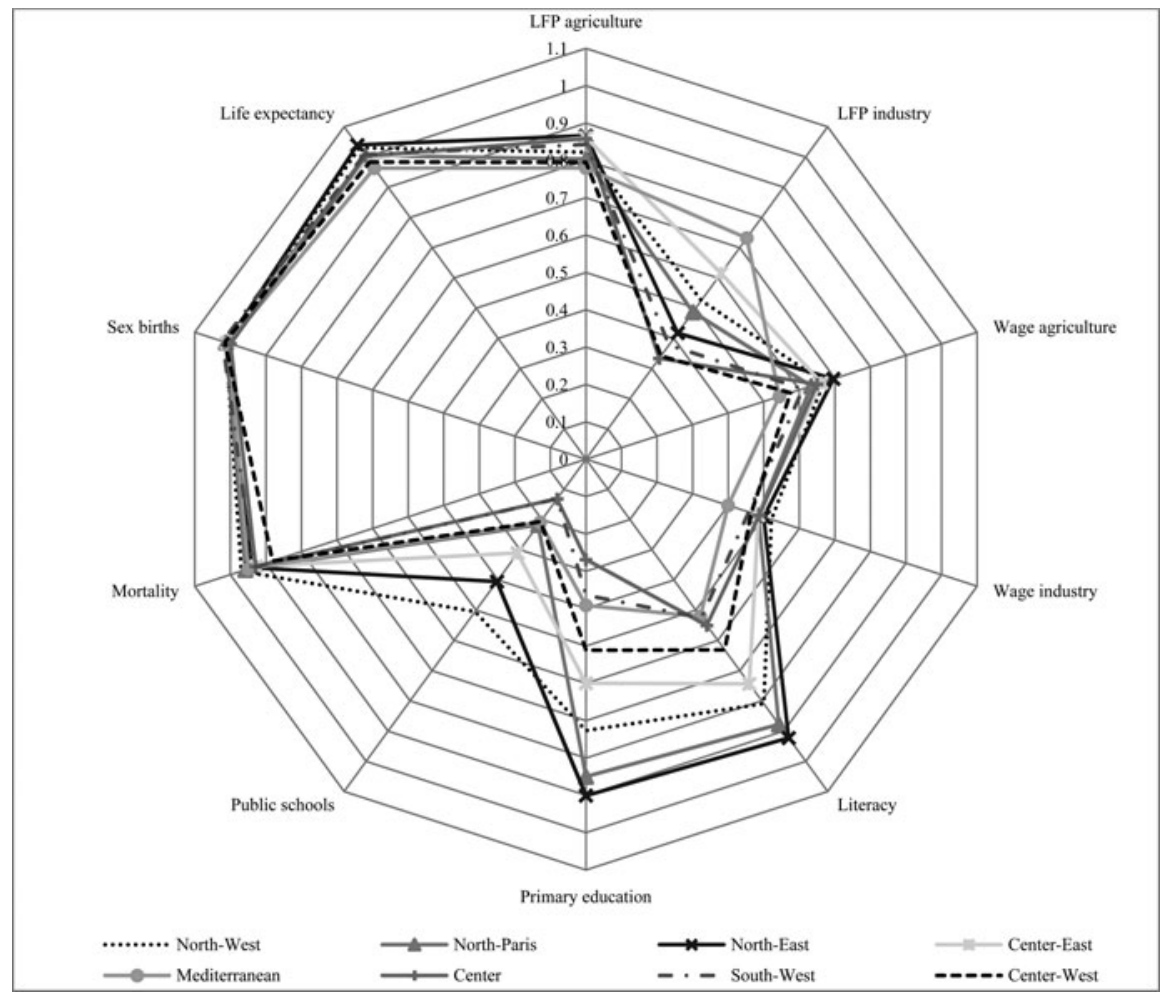

Figure A.3. Radar chart of regional profiles.

Cite this article: Perrin F (2022). Can the historical gender gap index deepen our understanding of economic development? Journal of Demographic Economics 88, 379-417. https://doi.org/10.1017/ $\operatorname{dem} .2020 .34$ 